\title{
Devonian and Mississippian Rocks of the Northern Antelope Range, Eureka County, Nevada
}

G E O L O G I C A L S U R V E Y P R O F E S S I O N A L P A P E R 1182 



\section{Devonian and Mississippian Rocks of the Northern Antelope Range, Eureka County, Nevada}

By RICHARD K. HOSE, AUGUSTUS K. ARMSTRONG, ANITA G. HARRIS, and BERNARD L. MAMET

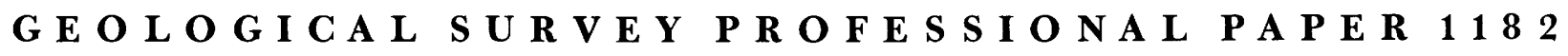

A summary of the biostratigraphy of Devonian and Mississippian rocks and their depositional history

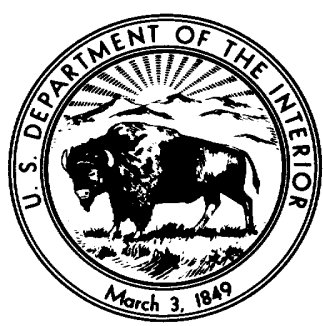




\title{
UNITED STATES DEPARTMENT OF THE INTERIOR JAMES G. WATT, Secretary
}

\author{
GEOLOGICAL SURVEY
}

Dallas L. Peck, Director

Library of Congress Cataloging in Publication Data

Devonian and Mississippian rocks of the northern Antelope Range, Eureka County, Nevada

(Geological Survey Professional Paper 1182)

Bibliography: p. 17.

1. Geology, Stratigraphic--Devonian. 2. Geology, Stratigraphic--Mississippian. 3. Geology--Nevada-Antelope Range.

I. Hose, Richard Kenneth, 1920- • II. Series. QE665.D44 551.7'4'0979332 81-607120 AACR2

For sale by the Superintendent of Documents, U.S. Government Printing Office Washington, D.C. 20402 


\section{CONTENTS}

\begin{tabular}{|c|c|c|c|}
\hline & Page & & Page \\
\hline - & 1 & Devonian stratigraphy-Continued & \\
\hline Introduction & 1 & Fenstermaker Wash Formation (new name)-Continued & \\
\hline Fossil collections & 1 & Facies and environments of deposition & 10 \\
\hline Devonian stratigraphy & 1 & Mississippian stratigraphy & 10 \\
\hline Beacon Peak Dolomite & 1 & Davis Spring Formation (new name) & 10 \\
\hline Lithology _ & 4 & Lithology $-1,-1$, & 10 \\
\hline Biostratigraphy & 5 & Biostratigraphy $\ldots \ldots \ldots$ & 11 \\
\hline Facies and environments of deposition & 5 & Facies and environments of deposition & 11 \\
\hline McColley Canyon Formation & 5 & Kinkead Spring Limestone (new name) & 12 \\
\hline Lithology & 5 & Lithology & 12 \\
\hline Biostratigraphy $\ldots \ldots \ldots \ldots$ & 6 & Biostratigraphy $\ldots \ldots$ & 12 \\
\hline Facies and environments of deposition & 8 & Facies and environments of deposition & 13 \\
\hline Denay Limestone & 8 & Antelope Range Formation (new name) & 14 \\
\hline Lithology & 8 & 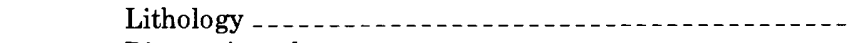 & 14 \\
\hline Biostratigraphy & 8 & Biostratigraphy $\ldots \ldots \ldots$ & 14 \\
\hline Facies and environments of deposition & 9 & Depositional environment & 15 \\
\hline Fenstermaker Wash Formation (new name) & 9 & Discussion & 15 \\
\hline Lithology $\ldots \ldots \ldots \ldots \ldots$ & 9 & References cited & 17 \\
\hline Biostratigraphy $\ldots \ldots$ & 10 & Index & 19 \\
\hline
\end{tabular}

\section{ILLUSTRATIONS}

[Plates follow references ]

Plate 1. McColley Canyon Formation, figs. A-F

2. McColley Canyon Formation, figs. A, B; Denay Limestone, figs. C-F

3. Denay Limestone, figs. A, B; Fenstermaker Wash Formation, figs. C-F

4. Fenstermaker Wash Formation, figs. A-F

5. Fenstermaker Wash Formation, figs A-E; McColley Canyon Formation, fig. F

6. Davis Spring Formation, fig A; Kinkead Spring Limestone, figs. B-F

7. Biostratigraphically significant conodonts from the McColley Canyon Formation and Denay Limestone

8. Biostratigraphically significant conodonts from the Fenstermaker Wash and Davis Spring Formations and the Kinkead Spring Limestone

FiguRe 1. Index map of central Nevada

2. Geologic map of northern Antelope Range

3. Generalized Devonian and Mississippian section

4. Chart showing distribution of biostratigraphically useful conodonts

5. Stratigraphic sections of Devonian formations

6. Stratigraphic sections of Mississippian formations _

7. Correlation of the Devonian and Mississippian rocks of the northern Antelope Range with the southern Fish Creek Range and the Newark Mountains

\section{TABLE}

TABLE 1. Distribution of foraminifers and algae in the Kinkead Spring Limestone 



\title{
DEVONIAN AND MISSISSIPPIAN ROCKS OF THE NORTHERN ANTELOPE RANGE, EUREKA COUNTY, NEVADA
}

\author{
By Richard K. Hose, Augustus K. Armstrong, Anita G. Harris, and Bernard L. Mamet ${ }^{\text {l }}$
}

\begin{abstract}
Lower through Upper Devonian rocks of the northern Antelope Range, Nev., consist of four formational rank units more than $800 \mathrm{~m}$ thick, separated from Mississippian units by an unconformity. The lower three Devonian units, the Beacon Peak Dolomite, McColley Canyon Formation, and Denay Limestone are known in other areas; the top unit, the Fenstermaker Wash Formation, is new. The Mississippian units, more than $280 \mathrm{~m}$ thick, are divisible into three units which are unlike coeval units elsewhere, and are herein named the Davis Spring Formation, Kinkead Spring Limestone, and Antelope Range Formation. Systematic sampling of the Devonian sequence has yielded relatively abundant conodonts containing several biostratigraphically significant taxa. The Mississippian units contain redeposited conodonts of chiefly Late Devonian and Early Mississippian (Kinderhookian) age together with indigenous Osagean foraminifers and algae in the Kinkead Spring Limestone.
\end{abstract}

\section{INTRODUCTION}

This paper discusses the stratigraphy, sedimentology, and micropaleontology of the Devonian and Mississippian rocks in the northern Antelope Range of central Nevada (fig. 1). This sequence consists of the Beacon Peak Dolomite, McColley Canyon Formation,

\footnotetext{
${ }^{1}$ University of Montreal.

${ }^{2}$ The Beacon Peak Dolomite, first recognized in the Eureka mining district, was designated a member of the lithologically diverse Nevada Formation (Nolan and others, 1956). Because the Beacon Peak-and, for that matter, every member of the Nevada Formation-possesses all the characteristics of a formation, we here elevate each of its members to formation rank and abandon the name Nevada Formation.
}

Denay Limestone, and Fenstermaker Wash Formation (new name) of Devonian age; and the Davis Spring Formation (new name), Kinkead Spring Limestone (new name), and Antelope Range Formation (new name) of Mississippian age. The distribution of these units, and the lines along which stratigraphic sections were measured, are shown in figure 2 , and a generalized stratigraphic section of all the units described herein is shown in figure 3.

\section{FOSSIL COLLECTIONS}

Conodonts were used to provide a biostratigraphic framework for all formations in the area of this report because of their well-established zonation in correlative rocks elsewhere, particularly in the Devonian and Lower Mississippian of the Great Basin (see, for example, Klapper, 1977; Sandberg and Gutschick, 1978; Sandberg and Poole, 1977) and because preliminary sampling showed them to be very well preserved and fairly abundant. Sample sizes ranged from 2 to $4 \mathrm{~kg}$ and about 80 percent of the samples yielded conodonts. Conodont-bearing samples are listed and the distribution of biostratigraphically significant conodont taxa are shown in figure 4 . The principal biostratigraphic indices in the Kinkead Spring Limestone are foraminifers; these were determined at 28 different levels. Conodonts in the three Mississippian formations appear to be redeposited.

\section{DEVONIAN STRATIGRAPHY BEACON PEAK DOLOMITE}

The Beacon Peak Dolomite is the oldest Devonian unit in the northern Antelope Range. Matti (1979) described the unit and its conodonts in some detail, and 


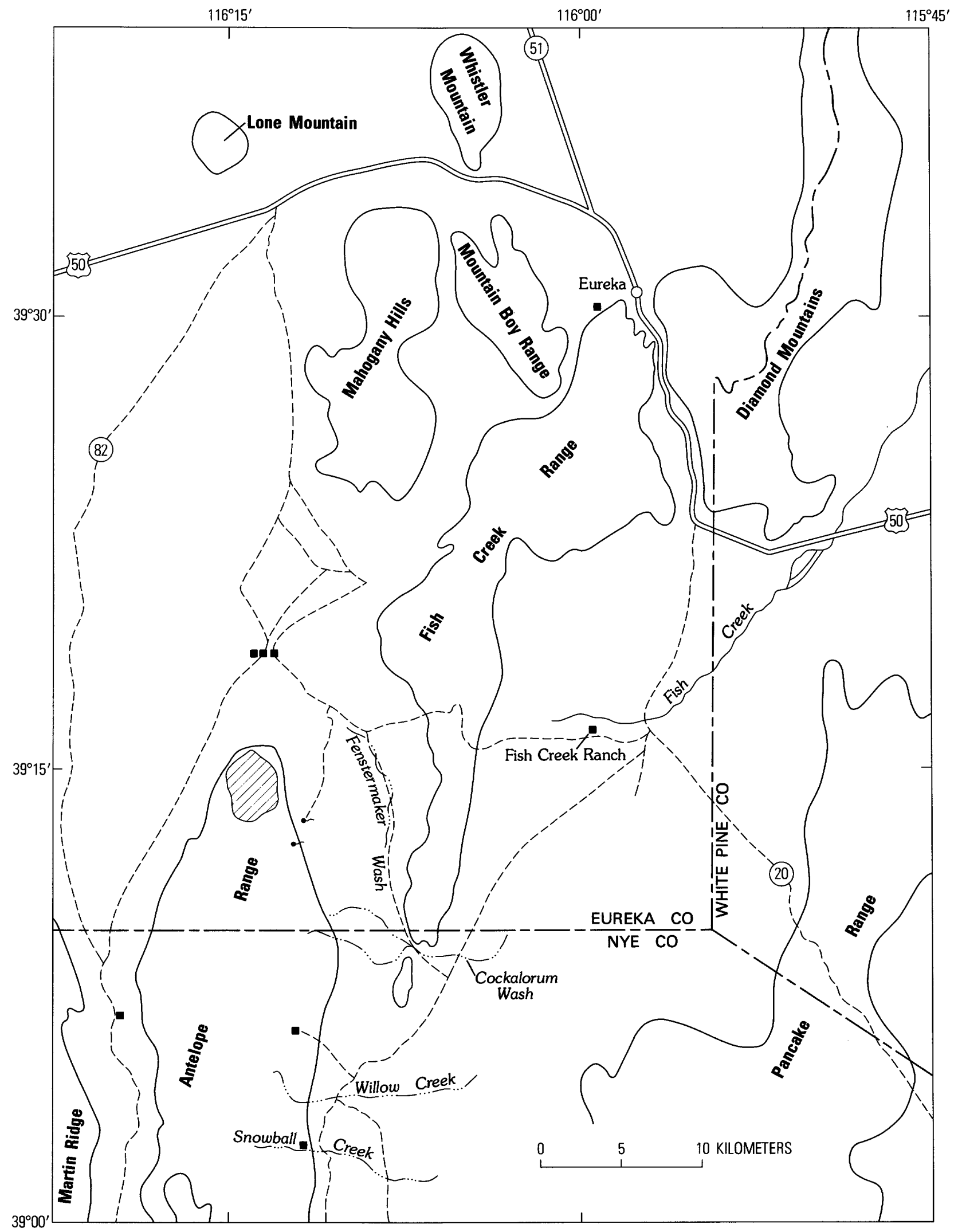

FIGURE 1.-Index map of part of central Nevada showing location of northern Antelope Range (hachures). 


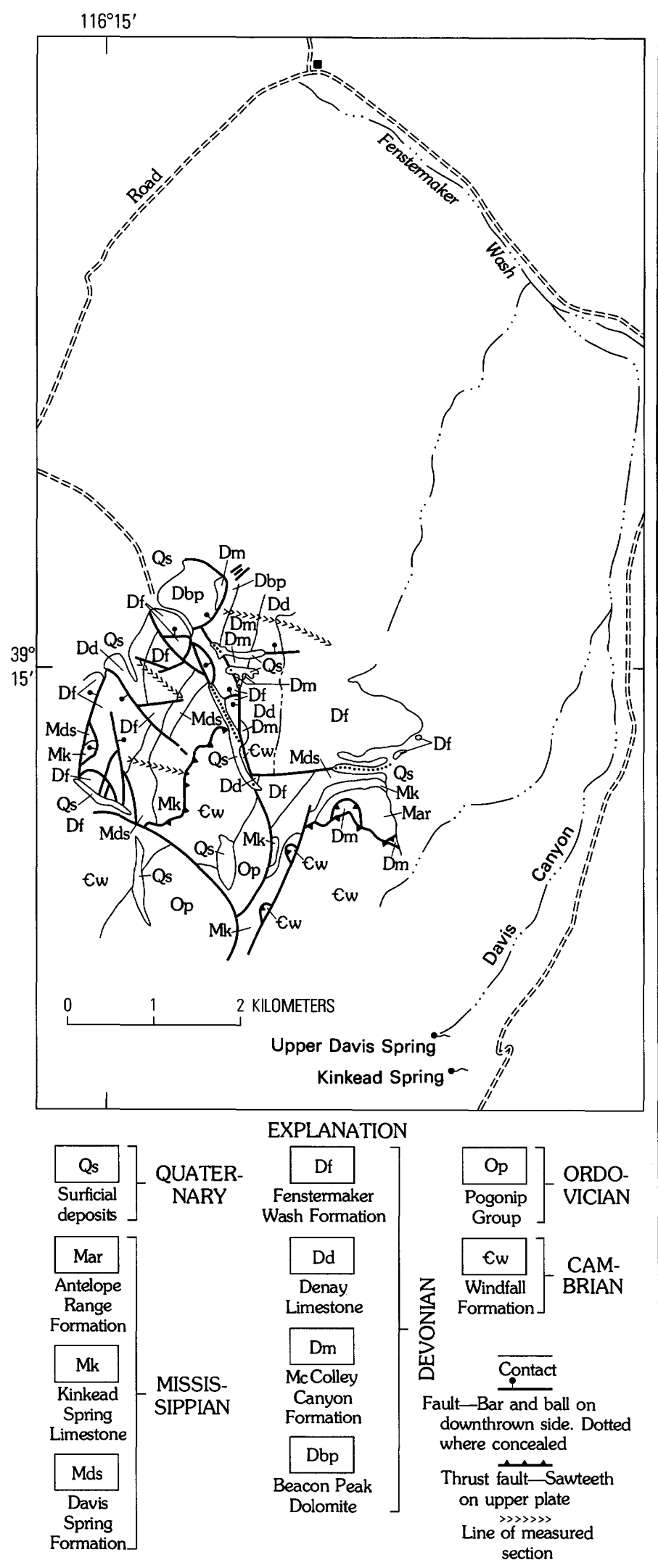

FIGURE 2.-Geologic map of northern Antelope Range and location of measured sections.

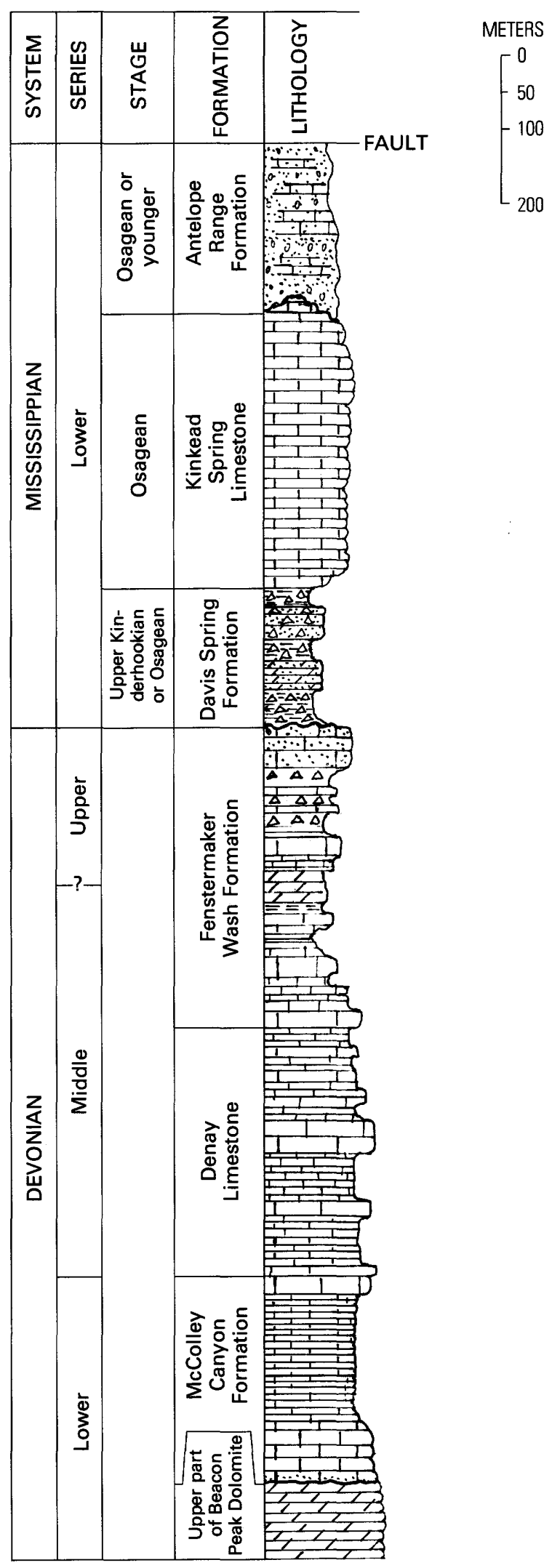

Figure 3.-Generalized Devonian and Mississippian section of the northern Antelope Range. (See figure 5 for explanation of symbols.) 
as a result we did not study or sample this unit as extensively as our other stratigraphic units.

\section{LITHOLOGY}

The Beacon Peak Dolomite is remarkable for its consistent lithology both vertically and laterally. It is mainly light-gray, finely crystalline dolomite in beds $1 / 3$ to $1 \mathrm{~m}$ thick. The beds are resistant and weather to angular blocks but do not form cliffs; rather, owing to their uniformity, they generally erode to smoothly fr rounded hills and knolls. The almost monotonous uniformity of the Beacon Peak is modified locally by a few finely laminated beds which alternate with massive structureless dolomite. Conodont-bearing beds of brownish-gray medium-grained petroliferous dolomite, about one-half meter thick, occur at 65 and $130 \mathrm{~m}$ below the top of the formation. Locally, thin lenses of quartz sandstone are present, as are thin beds of dolomite with abundant floating spheroidal grains of frosted quartz.

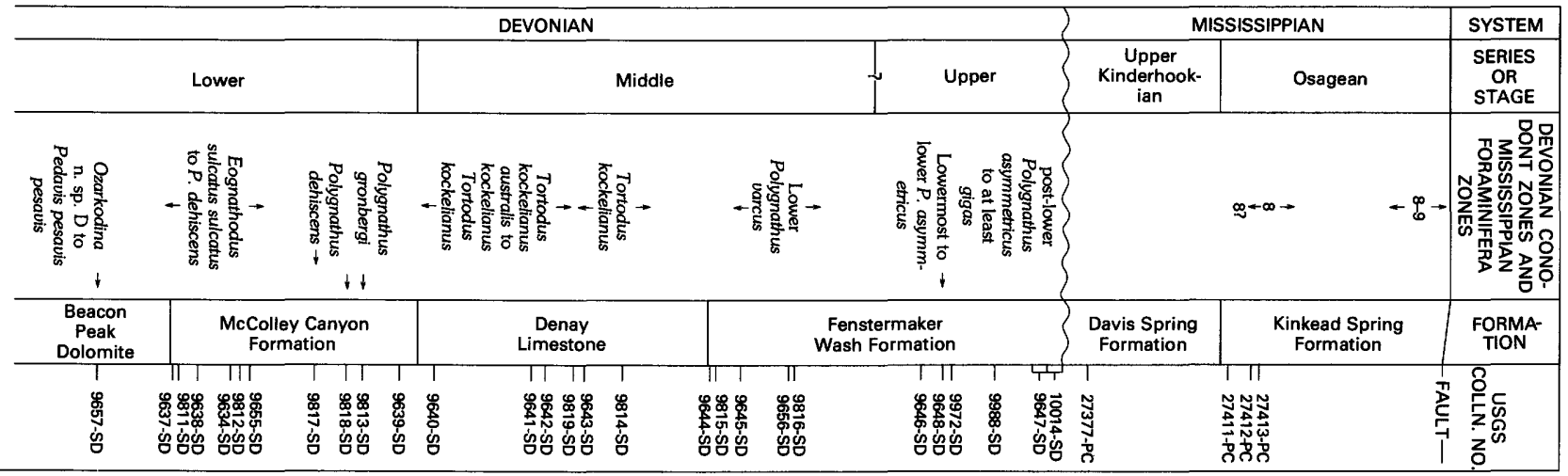

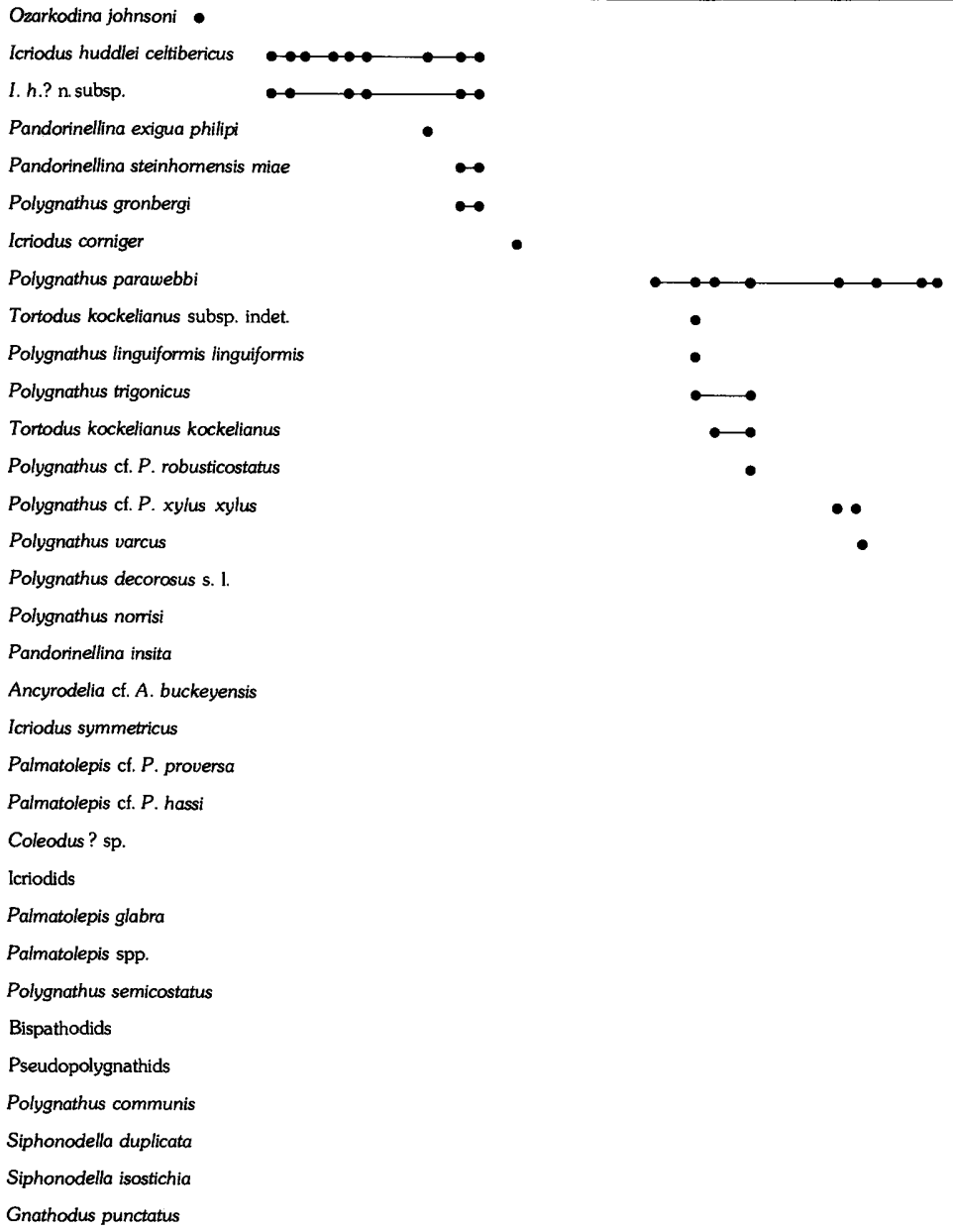

FIGURE 4.-Chart showing distribution of biostratigraphically useful conodonts. 


\section{BIOSTRATIGRAPHY}

The Beacon Peak Dolomite is lithologically identical to and coextensive with the Sevy Dolomite of eastern Nevada and western Utah. The basal meter of the Sevy Dolomite of western Utah has yielded a diverse marine fauna, including Paleocyclus identified by W. Oliver (written commun., 1961). Conodonts have also been obtained from about 30 and $34 \mathrm{~m}$ above the base of the Sevy in the Kings Canyon area of the Confusion Range (Matti, 1978), and gastropods from about $60 \mathrm{~m}$ above the base. Osmond (1954) reported the coral Halysites from the lower Sevy of the Egan Range, Nev. Osmond (1962) attributes to J. G. Johnson identification of Late Silurian marine fossils from the Sevy of the Pahranagat Range. Although such occurrences are unusual, they indicate either a marine origin for at least parts of the Beacon Peak and Sevy or that marine faunas were transported from nearby in tidal channels.

Two brownish-gray dolomite beds at 65 and $130 \mathrm{~m}$ below the top of the Beacon Peak Dolomite were sampled for conodonts. The lower sample yielded representatives of Pseudoneotodus beckmanni (Bischoff and Sannemann) and Ozarkodina remscheidensis? Ziegler, the latter indicating an age range of very latest Silurian to Early Devonian (into the Ozarkodina n. sp. D Zone of Klapper, 1977). The upper sample (USGS colln. 9657-SD, fig. 4) yielded abundant representatives of Ozarkodina aff. O. johnsoni Klapper indicating the Ozarkodina n. sp. D Zone or Pedavis pesavis Zone of the Lower Devonian.

\section{FACIES AND ENVIRONMENTS OF DEPOSITION}

Osmond (1962) interpreted the Beacon Peak-Sevy depositional site to have been shallow ponds and mud flats, the sediment being derived from an upland of Cambrian and Ordovician carbonate rocks to the east. He interpreted the laminations as the result of filling of shallow depressions within the mud flats, but did not specify whether the provenance carbonate was dolomite or limestone.

In fact, the Beacon Peak-Sevy depositional environment was more comparable to that of western Andros Island in the Bahamas, where dolomite is forming today in supratidal flats. In the Bahamas, as Folk and Land (1975) point out, gypsum is not accumulating in the supratidal flats owing to the higher rainfall and lower rates of evaporation, and they suggest that the dolomite may form from dilution of normal seawater by wet-season, rain water.

Stable isotope analyses of two specimens from the Beacon Peak are as follows:

\begin{tabular}{|c|c|c|c|}
\hline Sample & ${ }^{18} \mathrm{O}(\mathrm{SMOW})$ & ${ }^{13} C(P D B)$ & Yield $\mathrm{CO}_{2}$ \\
\hline $\mathrm{Ar}^{-}$ & $+25.60 \%$ & $-0.0002 \%$ & 90 percent \\
\hline Ar-2 & $+25.02 \%$ & $+0.13 \%$ & 89 per \\
\hline
\end{tabular}

These values indicate that the carbonate formed in marine waters.

\section{MCCOLLEY CANYON FORMATION}

In the Sulphur Springs Range, Carlisle, Murphy, Nelson, and Winterer (1957) named the sequence of limestone above the Lone Mountain Dolomite and beneath a quartzite sequence, the McColley Canyon Member of the Nevada Formation. Johnson later (1962) elevated the McColley Canyon to formation rank. In the northern Fish Creek Range, an equivalent but thinner unit above the Beacon Peak Dolomite and below a sandstone unit was called the Grays Canyon Limestone Member of the Nevada Formation by Nolan and others (1974). In the northern Antelope Range we follow Johnson's (1962) usage for the McColley Canyon Formation where it rests on the Beacon Peak Dolomite but is not overlain by sandstone.

\section{LITHOLOGY}

The McColley Canyon Formation is about $200 \mathrm{~m}$ thick and forms slopes that are broken here and there by thin ledges (fig. 5). It is composed of nearly all limestone except the lower $10 \mathrm{~m}$, which is light-brownishgray, fine-grained, organic detrital and fossiliferous dolomite. The basal one-half meter of this dolomite contains floating quartz sand grains almost certainly reworked from the underlying Beacon Peak Dolomite.

Most of the remaining rock is light-yellowish-gray to brownish-gray platy argillaceous limestone, mainly wackestone with minor packstone and dolomitic pelletal packstone. Calcareous shale is common 10 to $15 \mathrm{~m}$ above the base of the formation. The wackestone contains pellets of indeterminate origin and comminuted echinoderm and brachiopod debris. Both packstone and wackestone have the same kinds of clasts.

The upper $19 \mathrm{~m}$ of the McColley Canyon is an encrinite or crinoidal packstone, containing abundant distinctive crinoid columnals with double "axial" canals. Similar crinoidal limestone is present at Lone Mountain, $48 \mathrm{~km}$ to the north, in Merriam's (1973) Nevada Formation unit 3. The encrinite, which forms a resistant rounded bench, has a sharp contact with the wackestone. Transmission and scanning electron micrographs of specimens are shown in plate 1 .

Insoluble residues from the McColley Canyon contain abundant sponge spicules ( $\mathrm{pl}$. 2, fig. B), and subrounded to rounded quartz grains ( $\mathrm{pl} .5$, fig. $\mathrm{F}$ ) in the $400-$ to $500-\mu \mathrm{m}$ size range. Quartz, which makes up 1-5 percent of the unit, appears uniformly distributed throughout.

The contact between the McColley Canyon Formation and the underlying Beacon Peak Dolomite is characterized by light-gray dense dolomite below and lightolive-gray medium-grained dolomite directly above 


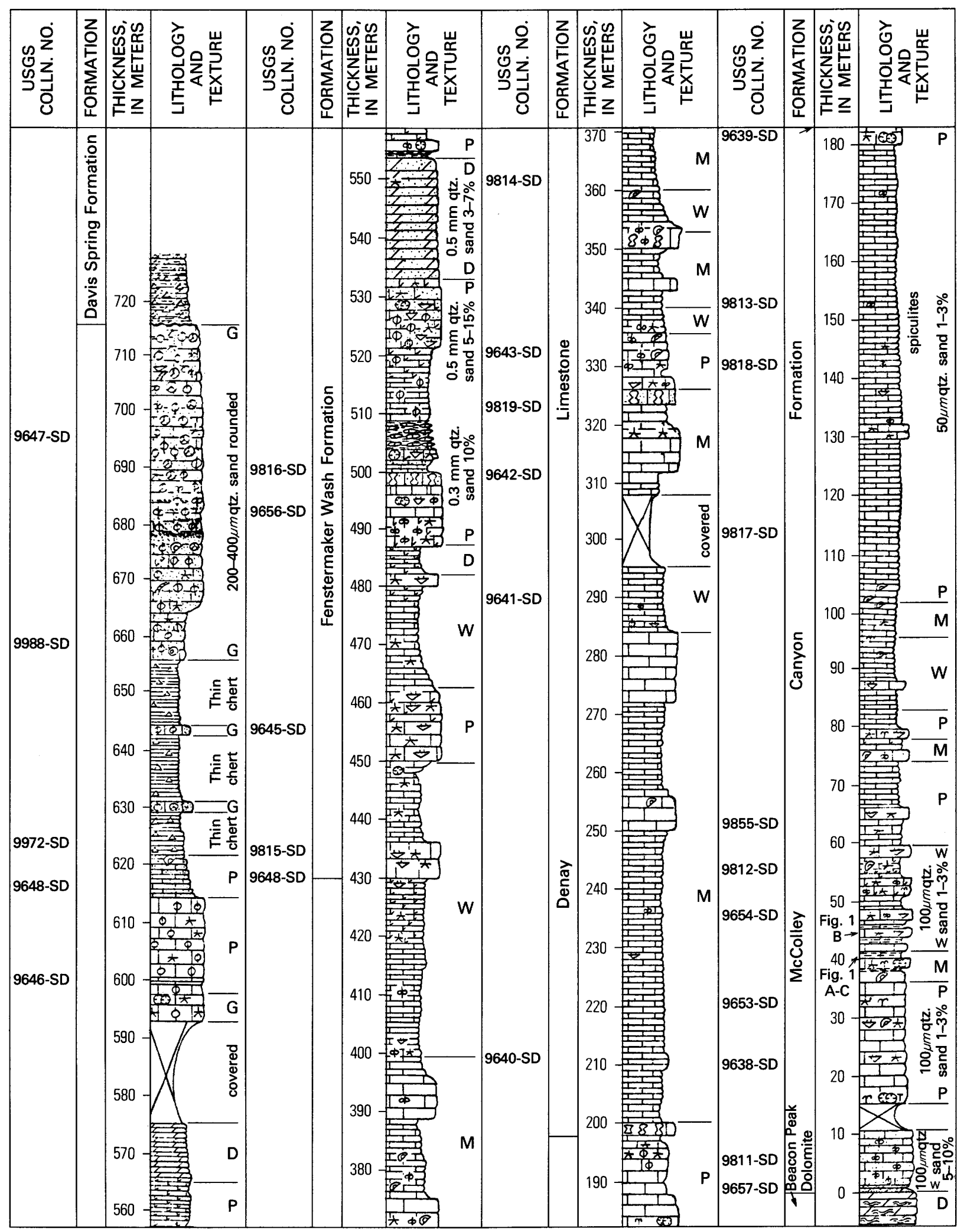

FIGURE 5.-Stratigraphic section of Devonian formations of northern Antelope Range showing lithology and microfossil collections. 
that gives way higher in the section to micrite and then to packstone. The McColley Canyon Formation forms slopes with scattered ledges in contrast to the ledgeforming Beacon Peak.

\section{BIOSTRATIGRAPHY}

Ten samples from the McColley Canyon yielded conodonts ( pl. 7, fig. 5). All samples contain an icriodid-panderodid-pseudoneotodid biofacies, characteristic of warm, shallow water, of which 90-95 percent are species of Icriodus (see Weddige and Ziegler, 1976). Only samples from $115 \mathrm{~m}$ above the base of the formation and higher contain representatives of Pandorinellina and (or) Polygnathus. Ichthyoliths are rare to common in all ten samples.

The base of the McColley Canyon Formation contains abundant icriodids, most of which conform to the description of Icriodus huddlei celtibericus Carls and Gandl (1969) (pl. 7, figs 1-3, 8, 9) and are the same as I. h. curvicauda of Klapper (1977) (Gilbert Klapper, oral commun., 1979). Within the icriodid population, however, there are several large icriodontan elements that are wider and have better developed spurs along the inner posterior margin than typical specimens of $I$. $h$. celtibericus; these are designated $I . h$. ? n. subsp. ( pl. 7 , figs. 4,5 ). In addition to icriodids, the lower part of the McColley Canyon contains a few representatives of Ozarkodina excavata (Branson and Mehl), panderodids, and pseudoneotodids. These, with the exception of $O$. excavata, are the only conodonts in the samples from the lower $63 \mathrm{~m}$ of the formation, and of these, only $I . h$. celtibericus is of biostratigraphic value. Its presence in- dicates that the lower $63 \mathrm{~m}$ of the McColley Canyon is probably no older than the Eognathodus sulcatus sulcatus Zone but could be as young as the Polygnathus dehiscens Zone based on the co-occurrence of $I$. h. celtibericus with indices of the $E$. sulcatus sulcatus and $E$. sulcatus $\mathrm{n}$. subsp. in other sections of the lower $\mathrm{McCol}$ ley Canyon Formation in central Nevada (Klapper, 1977, figs. 3, 5) and with $P$. dehiscens in succeeding collections in our section. Additional information on the lower age limit of the McColley Canyon comes from a conodont collection $60 \mathrm{~m}$ below the top of the underlying Beacon Peak Dolomite (USGS colln. 9657-SD) where it is contiguous with our measured section. The only conodonts in this collection are representatives of Ozarkodina aff. $O$. johnsoni Klapper, which indicates the Ozarkodina n. sp. D zone or Pedavis pesavis Zone. The Early Devonian age of this collection and the thickness of undated strata between it and the base of the McColley Canyon is compatible with our Early Devonian age determination for the lower McColley Canyon. The next collection, from $115 \mathrm{~m}$ above the base of the McColley Canyon, contains the same abundant icriodids and, significantly, a few representatives of Pandorinellina exigua philipi (Klapper) ( $\mathrm{pl}$. 7, figs. 10, 11) and one specimen of Polygnathus dehiscens Philip and Jackson. This sample is indicative of the $P$. dehiscens Zone of Klapper (1977). A sample from $142 \mathrm{~m}$ above the base of the formation contains specimens of Pandorinellina steinhornensis miae (Bultynck) and Polygnathus gronbergi, both of which also occur at 153 $\mathrm{m}$ above the base of the formation together with specimens that represent a form transitional between $P$. de-

\section{EXPLANATION}

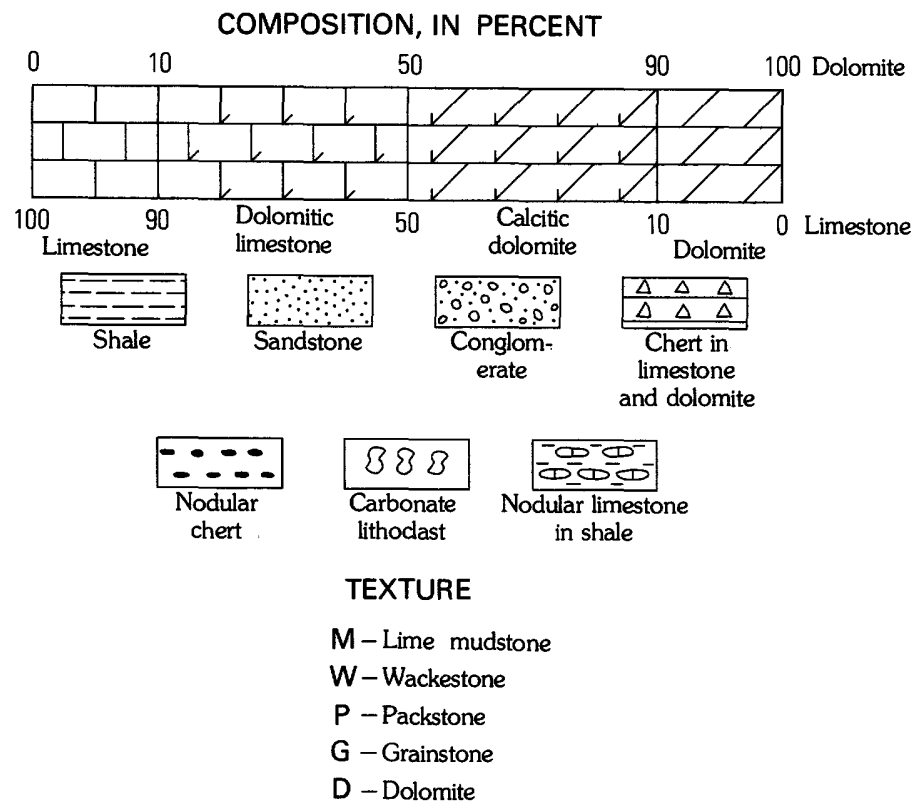

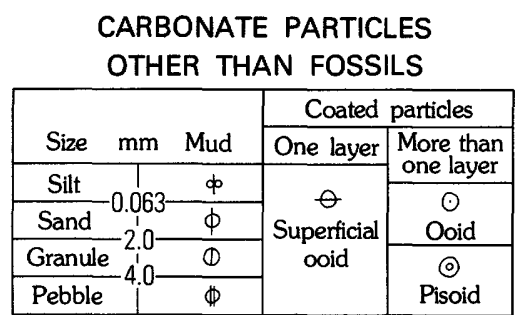

SYMBOLS FOR FOSSIL PARTICLES

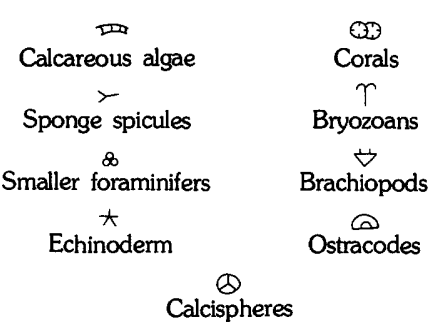

Figure 5.-Continued 
hiscens and $P$. gronbergi. Both samples also contain $I c$ riodus heddlei celtibericus together with a late form of I. $h$. ? n. subsp. that has developed a bilatericresid outline (a well-developed anteriorly projecting inner posterior spur; pl. 7, figs 6 and 7). This interval is assigned to the $P$. gronbergi Zone and may even belong in the lower part of this zone where $P$. gronbergi, $P$. dehiscens, and $P$. s. miae are known to occur together (Klapper, 1977, fig. 3).

The highest sample from the McColley Canyon, from $183 \mathrm{~m}$ above its base, contains chiefly representatives of Icriodus corniger Wittekindt ( pl. 7, figs. 16, 17) as well as a few polygnathid fragments that are indeterminate at the species level. The icriodids indicate a post-Polygnathus gronbergi, pre-Tortodus kockelianus kockelianus age; this interval encompasses the LowerMiddle Devonian transition. Thus, the McColley Canyon Formation in the northern Antelope is of late Early Devonian age and may extend slightly into the Middle Devonian. Klapper (1977) reported that the top of the McColley Canyon Formation at Lone Mountain lies within the Polygnathus serotinus Zone and is of Early Devonian age.

\section{FACIES AND ENVIRONMENT OF DEPOSITION}

The McColley Canyon Formation in the northern Antelope Range contains abundant well-preserved tabulate corals and some rugose corals in addition to abundant brachiopods. These assemblages suggest warm shallow marine depositional areas, perhaps sheltered lagoons with free access to marine waters and scattered patch reefs. The accumulation of lime mud precludes strongly agitated waters.

In 1977, Gilbert Klapper established a Lower Devonian and a preliminary Middle Devonian conodont zo. nation in central Nevada in limestone (including the type section of the McColley Canyon Formation) that were interpreted to have formed in continental slopeouter shelf and continental-shelf environments. The northern Antelope Range section lies just east of the sections studied by Klapper, and at least the Lower Devonian part (McColley Canyon Formation) formed nearer shore and contains less varied and fewer biostratigraphically useful conodonts than those parts studied by Klapper.

\section{DENAY LIMESTONE}

The Denay Limestone was named for the Denay Valley, which separates the northern Simpson Park Mountains from the northern Roberts Mountains. As originally defined by Johnson (1966) on the east flank of Willow Creek Canyon in the northern Roberts Mountains, the Denay rests on the McColley Canyon Formation and is overlain by the Devils Gate Limestone. We use the term in the northern Antelope Range for a sequence directly above the McColley Canyon and lithologically the same as the type Denay. In the northern Antelope Range, however, the Denay is overlain by the Fenstermaker Wash Formation rather than the Devils Gate Limestone.

\section{LITHOLOGY}

The Denay Limestone of the northern Antelope Range is $260 \mathrm{~m}$ thick and is predominantly argillaceous lime mudstone with a little wackestone and less packstone (fig. 5). Characteristically, the sequence is topographically recessive but it forms several massive benches 5-10 $\mathrm{m}$ thick. Beds range from 5 to $30 \mathrm{~cm}$ in thickness, the bedding surfaces being defined by laminae about 1 $\mathrm{mm}$ thick. In most exposures the limestone is even bedded and nonbioturbated. Most beds are 2.5-15 cm thick. The Denay is mainly gray to light olive gray, but brownish-gray tones are common. Tentaculites (Nowakia sp. and Striatolina sp.) are present on bedding surfaces in the lower $120 \mathrm{~m}$ and constitute a distinctive element of the formation (pl. 2, figs. C, D).

Thin-section and scanning electron microscope analyses show that the formation is carbonaceousargillaceous-dolomitic lime mudstone to wackestone. Dolomite rhombs $10-30 \mu \mathrm{m}$ in size are present in the micrite matrix, and clay minerals are present between the calcite crystals ( pl. 2, figs. D, E, F).

Echinoderm-peloid packstones and grainstones also occur within the Denay. The peloids contain isolated rhombs of dolomite in a lime mudstone matrix ( pl. 3, figs. A, B). Flat limestone pebbles as much as $15 \mathrm{~cm}$ long form a conglomerate 127-140 $\mathrm{m}$ above the base of the formation. The matrix of the conglomerate is quartz sand, broken corals, and bryozoans. The conglomerate is overlain by $1 \mathrm{~m}$ of crossbedded echinoderm packstone. Several beds in the sequence contain brachiopods.

The contact of the Denay and the upper crinoidal limestone of the underlying McColley Canyon Formation is topographically distinct. The recessive Denay forms a gentle slope above the rounded ledge of the McColley Canyon.

\section{BIOSTRATIGRAPHY}

Six samples of the Denay Limestone yielded conodonts, but only four contained biostratigraphically useful taxa. The Denay contains a polygnathid-belodellidpanderodid biofacies composed of 90-95 percent Polygnathus, 95 percent of which is $P$. parawebbi Chatterton. Ichthyoliths are less common than in the McColley Canyon Formation. The Denay also contains conodont pearls in almost every sample yielding conodonts ( pl. 7, fig. 18). These dimpled lamellar apatite spheres 
are also prevalent in our other conodont collections from Middle and lower Upper Devonian rocks in central Nevada. Apatite spheres associated with conodonts have been reported from Cambrian through Carboniferous rocks; Glenister, Klapper, and Chauff (1976) were the first to suggest that these are pearls secreted by the conodont-bearing animal.

The entire Denay appears to be of Middle Devonian age, even though the lower $92 \mathrm{~m}$ of the formation in the northern Antelope Range has not yet produced biostratigraphically diagnostic conodonts. The base of the Denay at its type section in the northern Roberts Mountains, however, has yielded lowermost Middle Devonian conodonts of the Polygnathus costatus costatus Zone (Klapper, 1977, fig. 5). Our lowest sample containing diagnostic conodonts is from $92 \mathrm{~m}$ above the base of the formation and contains Polygnathus parawebbi Chatterton. This sample is probably no older than the base of the Tortodus kockelianus australis Zone ( $P$. parawebbi has thus far not been found below the $T$. $k$. australis Zone in central Nevada; Klapper, 1977) and no younger than the Tortodus kockelianus kockelianus Zone, because stratigraphically higher collections contain representatives of $T . k$. kockelianus.

A sample from $125 \mathrm{~m}$ above the base of the formation contains abundant representatives of Polygnathus parawebbi ( $\mathrm{pl} .7$, fig. 21) and one specimen each of $P$. trigonicus Bischoff and Ziegler (pl. 7, fig 19), T. kockelianus subsp. indet., and $P$. linguiformis linguiformis Hinde morphotype indet. This collection is characteristic of the australis and T. $k$. kockelianus Zones. The T. $k$. kockelianus Zone is represented in collections from 134 and $164 \mathrm{~m}$ above the base of the formation. The lower collection contains only $T$. kockelianus kockelianus Bischoff and Ziegler, Polygnathus parawebbi, and panderodids. The upper collection, which is also our highest collection from the Denay, contains abundant $P$. parawebbi (pl. 7, fig 20) and belodellids as well as several specimens of $T$. $k$. kockelianus (pl. 7, figs. 22, 23), Polygnathus trigonicus, and $P$. cf. $P$. robusticostatus Bischoff and Ziegler. We have no other conodont collections from the remaining $67 \mathrm{~m}$ of the formation. $\mathrm{Col}-$ lections from the lower $5 \mathrm{~m}$ of the overlying Fenstermaker Wash Formation, however, are also of Middle Devonian age and contain conodonts of the lower subzone of the Polygnathus varcus Zone.

\section{FACIES AND ENVIRONMENTS OF DEPOSITION}

The principal faunal elements of the Denay Lime stone are pelagic forms: conodonts and, in the lower half, Nowakia sp., Striatolina sp., and sparse radiolarians. It seems that surface waters were normal marine but the bottom waters were generally euxinic.

The argillaceous lime mudstone accumulated in a marine environment of low wave energy, well below wave base. The presence of laminations suggests hostile bottom conditions that inhibited bioturbation. Occasionally, however, during the accumulation of the Denay, bottom conditions became more favorable for a restricted benthic fauna as indicated by a few thin beds containing brachiopods. A conglomerate containing broken corals, bryozoans, and quartz sand may have been a debris flow from the shelf-slope boundary area to the east.

Part of the Denay is the lithic correlative of the Woodpecker Limestone of the Newark MountainAlhambra Hills area; such a relation requires a similar depositional habitat. The area of the southern Diamond Mountains was a shallow sea during the deposition of the Sentinel Mountain Dolomite, deeper during deposition of the Woodpecker Limestone, and shallow again to produce the Bay State Dolomite.

\section{FENSTERMAKER WASH FORMATION}

Conformably overlying the Denay Limestone in the northern Antelope Range is a sequence of rock here named the Fenstermaker Wash Formation (fig. 5). We have subdivided it into a lower part, $80-183 \mathrm{~m}$ thick, a middle part $42 \mathrm{~m}$ thick, and an upper part $60 \mathrm{~m}$ thick. The variation in thickness of the lower part is probably a result of undetected faulting, most likely in the more northern section (fig. 2). The lower part was measured in the SE1/4 sec. 16 , T. $16 \mathrm{~N}$., R. $51 \mathrm{E}$., and NE1/4NE1/4 sec. 21 , T. 15 N., R. 51 E.; a second inner section of the lower part (the thinner one) was measured in the NE1/4NE1/4 sec. 20, T. 15 N., R. 51 E. The middle and upper parts were measured in the NE1/4 sec. 20 and NW1/4 sec. 21, T. 15 N., R. 51 E ( see fig. 2). The formation derives its name from Fenstermaker Wash, located northeast and east of the northern part of the Antelope Range.

\section{LITHOLOGY}

The lower part is made up principally of mediumgray to light-brownish-gray, massive, medium- to coarse-grained, peloid-echinoderm-coral, stromatoporoid-brachiopod packstone and wackestone (pl. 3, figs. C, D). Dolomite of coarse texture is common 100 to $124 \mathrm{~m}$ above the base of the formation (pl. 3, figs. E, D; pl. 4, figs. A-F). Yellowish platy silty fine-grained limestone that forms slopes is present from 124 to 160 $m$ above the base. The lower unit contains corals, brachiopods, crinoid columnals, and Receptaculites more than $1 \mathrm{~cm}$ thick and as much as $20 \mathrm{~cm}$ across.

The middle part is mainly pale-yellowish-orange siliceous laminated siltstone and claystone. It includes some thin beds of wackestone to packstone, which contain sparse fish remains. This unit generally forms slopes that are poorly exposed. 
The upper part of the formation is medium-gray crossbedded peloid-mudlump packstone to grainstone. Calcispheres and ostracodes are present. About 40 percent of the rock is medium-sized subequant wellrounded quartz that occurs as floating grains in lenses and stringers. This topmost unit forms a massive and prominent cliff.

The contact of the Fenstermaker Wash Formation with the underlying Denay is sharp. Medium-gray to medium-dark-gray even-bedded lime mudstone below is succeeded by light-yellowish-gray medium- to coarse-grained packstone that forms cliffs.

\section{BIOSTRATIGRAPHY}

Nine of eleven collections from the Fenstermaker Wash Formation have biostratigraphically useful taxa. The formation is of Middle and Late Devonian age and contains a polygnathid-belodellid-panderodid biofacies including at least 90 percent Polygnathus in its Middle Devonian part and a polygnathid-palmatolepid-icriodid biofacies including 90 percent Polygnathus in its Upper Devonian part. Conodont "pearls" are abundant to rare in most samples; ichthyoliths are present but rare.

The lower $70 \mathrm{~m}$ of the formation is no younger than the lower Polygnathus varcus Subzone of the $P$. varcus Zone based on the co-occurrence of Polygnathus varcus Stauffer (pl. 8, fig. 3) and P. parawebbi (pl. 8, figs. 1, 2). $P$. varcus first occurs and $P$. parawebbi last occurs in the lower $P$. varcus Subzone (Ziegler and others, 1976). Representatives of $P$. parawebbi are the most abundant conodonts in this part of the formation, just as they are in the underlying Denay Limestone.

We have no conodonts from the overlying $100 \mathrm{~m}$ and only a few indeterminate bar and platform fragments in a collection from $170 \mathrm{~m}$ above the base of the formation. A collection at $187 \mathrm{~m}$ above the base contains conodont species whose ranges cross what is commonly considered to be the Middle-Upper Devonian boundary (the boundary between the lowermost and lower Polygnathus asymmetricus Subzones). These include abundant representatives of Polygnathus decorosus s. $l$. (Ziegler, 1966) and several specimens of Polygnathus norrisi Uyeno ( $\mathrm{pl}$. 8, fig. 6) and Pandorinellina insita (Stauffer) (pl. 8, fig. 7). Of these, $P$. norrisi appears to be restricted to the lowermost and lower $P$. asymmet ricus Subzones; the collection is assigned to this interval. $P$. decorosus s. $l$. ( $\mathrm{pl} .8$, figs. 4,5 ) continues to be the most abundant species at $193 \mathrm{~m}$ above the base of the formation, where it occurs with several specimens of Icriodus symmetricus Branson and Mehl (pl. 8, figs. $8,9)$, one juvenile and several incomplete adult specimens of Palmatolepis cf. P. proversa Ziegler ( $\mathrm{pl} .8$, fig. 11) and one juvenile specimen of Ancyrodella cf. A. buckeyensis Stauffer ( $\mathrm{pl}$. 8, fig. 10). This collection is no older than the middle $P$. asymmetricus Subzone and probably no younger than the lower Palmatolepis gigas Subzone. P. decorosus s. $l$. and a few juvenile and fragmentary palmatolepids occur at $230 \mathrm{~m}$ above the base of the formation, and only incomplete palmatolepids that compare well with Palmatolepis hassi Muller and Muller (pl. 8, fig. 12) occur in a collection at $260.270 \mathrm{~m}$ above the base of the formation. Our highest sample is from the upper meter of the formation (USGS colln. 10014-SD) and was collected and processed after the fossil plates had been prepared. This 6-kg sample yielded representatives of Ancyrodella buckeyensis Stauffer and Palmatolepis gigas Miller and Youngquist as well as other less diagnostic conodonts. The overlapping ranges of these two species indicate that the lower or upper $P$. gigas Subzone (Frasnian) is represented at the top of the Fenstermaker Wash Formation in our measured section.

\section{FACIES AND ENVIRONMENTS OF DEPOSITION}

The lower unit of the Fenstermaker Wash Formation contains a fauna suggestive of warm intertidal to subtidal marine deposition. The environment was also one of proximity to strong wave and current action, for the sequence is largely calcarenite whose clasts are derived from marine invertebrates. Parts of the lower unit may well be debris flows.

The middle unit of laminated siltstone and claystone suggests a deeper water environment and a high influx of fine-textured terrigenous silt and clay. A few coarse-textured wackestone to packstone beds may be debris flows. The top unit contains calcispheres, peloidal mudlump packstone to grainstone, and a large admixture of quartz grains. It is crossbedded in part and probably represents a shallow, shoaling subtidal depositional site.

\section{MISSISSIPPIAN STRATIGRAPHY}

\section{DAVIS SPRING FORMATION (NEW NAME)}

The name Davis Spring Formation is applied to a $125-\mathrm{m}$-thick sequence of slope-forming rock above the Fenstermaker Wash Formation in the SE1/4 sec. 20, T. 16 N., R. 51 E. This sequence is considered its type section. The name is derived from Upper Davis Spring, about $3 \mathrm{~km}$ southeast of the measured section (fig 2).

\section{LITHOLOGY}

The Davis Spring Formation is very fine grained pale-brown siliceous dolomitic siltstone and finely laminated chert (fig. 6). The upper $15 \mathrm{~m}$ or so of the formation is slightly more siliceous than the rest of the unit, but the proportion of silica throughout is significant. Quartz is present as silt-size grains and as what appears in some thin sections to be cement or secon- 
dary partial replacement. A translucent pale-brown pigment, presumably organic, is present at some levels. In some zones small clusters of hematite are present, and some is secondary after pyrite. The only fossils found in thin sections are sparse radiolarians (pl. 6, fig. A) although conodonts were obtained $18 \mathrm{~m}$ above the base of the formation.

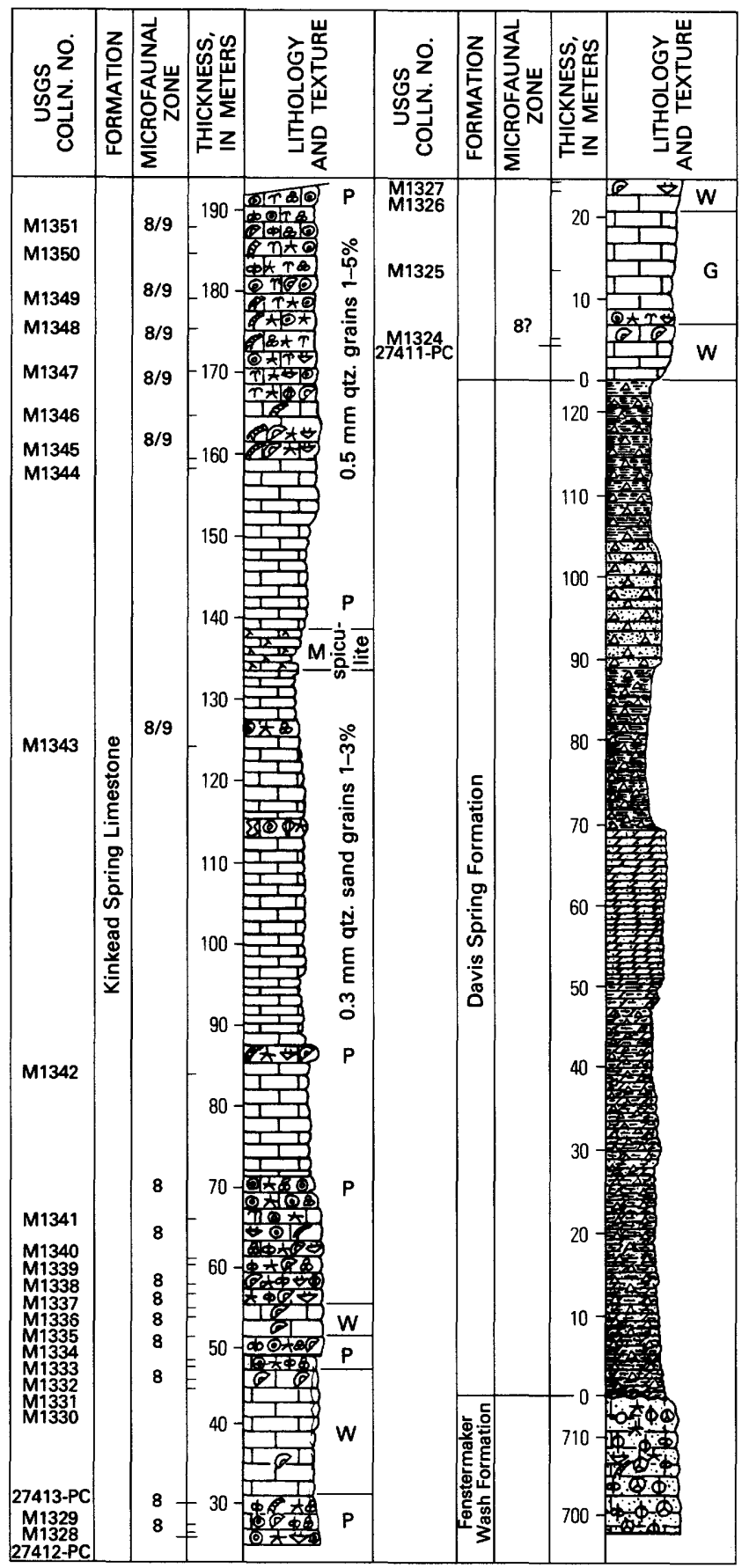

FIGURE 6.-Stratigraphic section of Mississippian formations of northern Antelope Range showing lithology and microfossil collections. (See figure 5 for explanation of symbols.)
Dolomite is present mainly as very fine irregularly shaped grains in the silt size range, but rhombs are not uncommon. A small amount of illite is present in nine samples from various levels throughout the formation. Kaolinite in very small quantities is present in a few samples. Fine laminations are clearly visible in thin sections from each of about ten different levels in the sequence. The unit is finely laminated throughout and is not bioturbated.

The contact with the underlying Fenstermaker Wash Formation is very sharp. Beds below the contact form a resistant massive limestone cliff; those above form slopes. The topmost one meter of the underlying Fenstermaker Wash Formation contains conodonts no younger than upper $P$. gigas Subzone and the contact therefore represents an unconformity of considerable magnitude.

\section{BIOSTRATIGRAPHY}

Our only conodont collection from the Davis Spring Formation is from $20 \mathrm{~m}$ above its base. The collection contains hundreds of conodont fragments as well as many complete to nearly complete specimens, most of which have numerous fractures. The conodonts are representative of Devonian and Mississippian species, and most if not all of them are redeposited. Late Devonian forms are more abundant than Mississippian forms. The Devonian elements, chiefly of Famennian age, are palmatolepids, mainly Palmatolepis glabra Ulrich and Bassler (pl. 8, fig. 13), and Polygnathus semicostatus Branson and Mehl (pl. 8, fig. 16), and icriodids. The Mississippian elements are Gnathodus delicatus Branson and Mehl, G. punctatus (Cooper) (pl. 8, fig. 15), and Siphonodella isosticha (Cooper). The collection also contains several specimens of Polygnathus communis Branson and Mehl and one bispathodid; these could be components of the Devonian fauna, the Mississippian fauna, or possibly both faunas. The youngest conodonts in the collection are chiefly of late Kinderhookian age, although G. punctatus and $P$. communis can range into the Osagean. Thus, the Davis Spring Formation is no older than late Kinderhookian but might be of Osagean age because even the youngest conodonts could be redeposited. The overlying Kinkead Spring Limestone is of middle? to late Osagean age.

\section{FACIES AND ENVIRONMENTS OF DEPOSITION}

The Davis Spring Formation is finely laminated siliceous dolomite with organic pigment in the matrix. The unit appears not to be bioturbated and has yielded conodonts, some of which were redeposited from Devonian strata, and radiolarians. The abundance of organic material, paucity of benthic fossils, and lack of bioturbation suggest euxinic bottom waters and oxy- 
genated upper levels of marine waters that supported a limited pelagic fauna. The sediment accumulated below wave base. The dolomite may have resulted from hypersalinity of the water close to the bottom; however, no features normally associated with hypersaline deposits were found.

\section{KINKEAD SPRING LIMESTONE (NEW NAME)}

The name Kinkead Spring Limestone is herein applied to more than $160 \mathrm{~m}$ of limestone and associated rock that overlies the Davis Spring Formation in its type section measured in SE1/4 sec. 20 and SW1/4 sec. 21 , T. 16 N., R. $51 \mathrm{E}$ (fig. 1). The name is derived from Kinkead Spring, about $4 \mathrm{~km}$ southeast of the measured section.

The thickness of the Kinkead Spring Limestone cited above is a minimum amount as the upper part of the formation is here a thrust fault (fig. 6). Furthermore, there is a 20 - to $30-\mathrm{m}$ covered zone just under the thrust in which scattered outcrops and float, which are mixed with float from the overlying Cambrian rocks, suggest that Kinkead lithology persists through more than $220 \mathrm{~m}$. The upper $60 \mathrm{~m}$ or so was collected for microfossils about $2 \mathrm{~km}$ southwest of the map area just north of Ninemile Canyon.
LITHOLOGY

The formation is composed mainly of packstone to grainstone and minor wackestone and micrite ( $\mathrm{pl} .6$, figs. B-F). The clasts are made up of peloids, ooids, skeletal fragments, foraminifers, algae, and, at some levels, scattered silt-sized quartz grains. Sparse lithoclasts, apparently derived from the Davis Spring Formation, occur $50 \mathrm{~m}$ above the base. Most of the clasts range in size from medium to coarse. Colors are mainly medium gray to gray, but some light-olive-gray to yellowish-gray zones are present. Most of the sequence is thin bedded or even platy, but several beds $1 / 2$ to 1 $\mathrm{m}$ thick form ledges.

The contact of the Kinkead Spring Limestone with the underlying Davis Spring Formation is sharp; beds below are pale-brown to reddish-brown slope-forming platy siliceous dolomite, whereas those above are gray medium- to coarse-grained more resistant limestone.

\section{BIOSTRATIGRAPHY}

Three conodont collections from the Kinkead Spring Limestone are from the lower $30 \mathrm{~m}$. They contain the

TABLE 1.-Distribution of foraminifers and

\begin{tabular}{|c|c|c|c|c|c|c|c|c|c|c|c|}
\hline USGS locality number & M1324 & M1325 & M1326 & M1327 & M1328 & M1329 & M1330 & M1331 & M1332 & M1333 & M1334 \\
\hline \multicolumn{12}{|c|}{ Height above base (in meters) } \\
\hline & 5 & 14 & 23 & 25 & 26 & 28 & 43 & 44 & 46 & 48 & 51 \\
\hline Sphaeroporella sp. & $x$ & -. & .. & -. &.. & $\therefore$ & .. & .. & 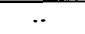 & .. & .. \\
\hline Calcisphaera sp. & .. & $x$ & $x$ & .. & $x$ & .. & .. & -. & .. & .. & $x$ \\
\hline Calcisphaera laevis Williamson. & .. & .. & .. & $x$ & .. & -. & .. & $x$ & .. & .. & -. \\
\hline Columbiapora sp. & .. & -. & .. & -. & .. & $x$ & .. & .. & -. & .. & .. \\
\hline Columbiapora johnsoni Mamet & .. & .. & $x$ & $x$ & .. & .. & .. & -. & -. & $x$ & .. \\
\hline Radiospheres _ & .. & $x$ & .. & .. & .. & -. & .. & .. & .. & .. & .. \\
\hline Kamaenid algae & .. & .. & .. & .. &.. & -. & $x$ & .. & .- & .. & .. \\
\hline Kamaena sp. & $x$ & .. & .. & $x$ & .. & .. & .. & $x$ & $x$ & .. & .. \\
\hline Kamaena delicata Antropov & -. &.$\cdot$ & .. & -. &.$\cdot$ & -- & $\cdot \cdot$ & $\cdot-$ & -. & -. & .. \\
\hline Kamaenella sp. & -. & .. & .. & .. & .. & -. &.$\cdot$ & .. & .. & .. & -. \\
\hline Issinella sp. _. & .. & .. & .. & .. & .. & .. & .. & .. & $x$ & .. & .. \\
\hline Moravammina sp. & .. & .. & .. & .. & .. & $x$ & .. & .. & .. & -. & .. \\
\hline - & .. & .. & .. & .. & .. & .. & $x$ & .. & .. & .. & .. \\
\hline Eovolutina sp. & -. & .. & -. & .. & .. & .. &.. & .. & .. & $x$ & .. \\
\hline Asphaltinella $\mathrm{sp}$. & -. & .. & $x$ & -. & -. & $x$ & -. & -. & $\cdot \cdot$ & $x$ & .. \\
\hline Pekiskopora sp. & -. & .. & .. & .. & .. & .. & .. & .. & .. & .. & .. \\
\hline Palaeoberesella sp. & $\times$ & .. & .. & -. & .. &.. & -. & .. & .. & -. & $x$ \\
\hline Palaeoberesella lahuseni (Von Moller) & .. & .. & $x$ & .. & .. & .. & .. & .. & .. & .. & .. \\
\hline Earlandia sp. & .. & .. & .. & $x$ & .. & .. & .. & .. & .. & .. & .. \\
\hline Parathurammina sp. & $x$ & $x$ & -. & $-\cdot$ & $x$ & -. & $x$ & $\cdots$ & -. & .. & -. \\
\hline Septabrunsina sp. & $x$ & -. & -. & $x$ & -. & .. & .. & $x$ & .. & .. & .. \\
\hline Septaglomospiranella sp. ....... & $x$ & .. & .. & $\hat{x}$ & -. & $x$ & -. & .. & $\ddot{x}$ & .. & .. \\
\hline Septaglomospiranella primaeva & & & & & & & & & & & \\
\hline (Chernysheva) & .. & .. & .. & -. & .. & -. & .. & $x$ & -. & .. & *. \\
\hline Rectoseptaglomospiranélla sp. & .- & -. & -. & .. & .. & .. & .. & -- & .. & -. & $-\cdot$ \\
\hline Latiendothyra sp. & $x$ & .. & $-\cdot$ & $\times$ & -. & .. & .. & $x$ & $x$ & -. & $-\cdot$ \\
\hline Tuberendothyra sp. & $x$ & .. & .. & $x$ & .. & .. & .. & -. & $x$ & .. & .. \\
\hline Tuberendothyra tuberculata (Chernysheva) & .. & .. & -. & .. & .. & .- & $x$ & -. & .. & .. & \\
\hline Septatournayella sp. & .. & .. & .. & .. & .. & -. & .. & -. & $x$ & .. & .. \\
\hline cf. Spinoendothyra sp. & .. & .. & .. & .. & .. & .- & -. & -. & -. & .. & -. \\
\hline "Nostocites" sp. &.$\cdot$ & $\cdot \cdot$ & $\cdot \cdot$ & $\cdot \cdot$ & $\cdot \cdot$ & $\cdot \cdot$ & $\cdot \cdot$ & $\cdot \cdot$ & $\cdot-$ & .. & $\cdot \cdot$ \\
\hline Brunsiina sp. & .. & .. & .. & $x$ & .. & .. & .. & .. & $x$ & .. & .. \\
\hline Glomospiranella sp. & .. & .. &.. & .. & .. & .. & .. & .. & .. & .. & .. \\
\hline
\end{tabular}


same abundant mixed fauna of Late Devonian and Early Mississippian (Kinderhookian) species described from the underlying Davis Spring Formation. The Kinkead Spring, however, contains foraminifers of Osagean age; representatives of Mamet's Zone 8 occur in its lower $80 \mathrm{~m}$, and species that range across the 8-9 zonal boundary are present from $125 \mathrm{~m}$ to about $190 \mathrm{~m}$ above its base (table 1). The foraminifers are interpreted as indicating that the Kinkead Spring was deposited in Osagean time. The foraminifers also suggest that all the conodonts in our collections from the Kinkead Spring were redeposited, with the possible exception of Gnathodus punctatus and Polygnathus communis.

The collections contain more Devonian than Mississippian specimens; all contain palmatolepids, dominantly Palmatolepis glabra, Gnathodus delicatus (pl. 8, fig. 22), Gnathodus punctatus, Gnathodus delicatus ( $\mathrm{pl}$. 8, fig. 19), and Siphonodella isosticha. In addition to these, the following fossils have also been noted: bispathodids, a Middle Ordovician Coleodus? sp. ( $\mathrm{pl} .8$, fig. 17), characteristic of the lower Middle Ordovician in part of the Antelope Valley Limestone in central Nevada, and conodont "pearls" at $5 \mathrm{~m}$ abgve the base of the formation; Polygnathus semicostatus, Siphonodella duplicata (Branson and Mehl), and pseudopolygnathids at $25 \mathrm{~m}$ above the base; and $S$. duplicata (pl. 8, fig. 21) and icriodids (pl. 8, fig. 18) at $30 \mathrm{~m}$ above the base.

The reworked conodonts in the Davis Spring and Kinkead Spring Formations indicate that chiefly Famennian (latest Devonian) and Kinderhookian (Early Mississippian) deposits were being eroded during the deposition of these formations and that even lower Middle Ordovician rocks were then exposed to erosion.

The microfossils within the Kinkead Spring Limestone are Tournaisian (Osagean) Zone 8 in age in the lower $70 \mathrm{~m}$. The upper $70-80 \mathrm{~m}$ of limestone are zone $8 / 9$ transition. The upper Tournaisian, zone 8 , is characterized by Tuberendothyra tuberculata (Chernysheva) while Septebrunsiina and Rectoseptaglomospiranella are progressively eliminated. The acme of Spinoendothyra accompanied by spinose tournayellids is characteristic of zone 9 . The microfossil assemblage of the Kinkead Spring Limestone of the Antelope Range is widespread in the Cordillera of North America, occurring in the Wachsmuth Limestone of the central Brooks Range, Alaska (Armstrong and Mamet, 1977), Shunda Formation of the Canadian Rocky Mountains (Mamet, 1976; Bamber and Mamet, 1978), the lower part of the Mission Canyon Limestone of Montana and western Wyoming, the Madison Limestone of central Wyoming (Sando and others, 1969), the Thunder Springs Member of the Redwall Limestone

algae in the Kinkead Spring Limestone

\begin{tabular}{|c|c|c|c|c|c|c|c|c|c|c|c|c|c|c|c|c|}
\hline M1335 & M1336 & M1337 & M1338 & M1339 & M1340 & M1341 & M1342 & M1343 & M1344 & M1345 & M1346 & M1347 & M1348 & M1349 & M1350 & M1351 \\
\hline \multicolumn{17}{|c|}{ Height above base (in meters) } \\
\hline 53 & 54 & 57 & 58 & 60 & 61 & 67 & 83 & 123 & 158 & 159 & 165 & 170 & 175 & 180 & 185 & 190 \\
\hline .. &.. & -. &.. & .. & $x$ &.. & $x$ & .. & .. & .. & -. & .. & .. & .. & .. & .. \\
\hline$x$ & -. & -. & $x$ & -. & $x$ &.. &.. & $x$ & $x$ & .. & $x$ & $x$ & $x$ & $x$ & $x$ & $x$ \\
\hline .. & $x$ & .. & .. &.. & .. & .. & -. & .. & .. & $x$ & .. & .. & .. & .. & .. & .. \\
\hline -. & .. & $\cdot \cdot$ & .. & $\cdot \cdot$ & .. & $x$ & .. & .. &.. & .. & -. & $x$ & $x$ & .. &.. & .. \\
\hline .. & -. & -. & $\cdot \cdot$ & $x$ & $x$ & .. & $-\cdot$ & .. & -. &.. & .. & .. & .. & .. & .. & .. \\
\hline.. & .. & .. & .. & .. & .. & .. & $x$ & .. & $x$ & $x$ & $x$ & .- & .. & -. & .. & $x$ \\
\hline .. & -. & -. & .. & $\cdot \cdot$ & .. & .. & $x$ &.. & $x$ & $x$ &.. & .. & .. & .. & .. & $x$ \\
\hline -. & .. & -. &.$\cdot$ & $x$ & .. & .. & -. & $\times$ & .. &.. &.. & $x$ & .. & $x$ & $x$ & $x$ \\
\hline -. & .. & .. & -. & $\cdots$ & .. & .. & .. & .. & .. &.. & .. & .. & $x$ & $x$ & .. & .. \\
\hline .. & -. & $-\cdot$ & -. & -. & .. & .. &.. & .. & -. & .. & $\cdot \cdot$ & .. & .. & .- & .. & $x$ \\
\hline .. & .. & .. & .. & -. & .. & .. & .. & .. & .- & .. & .. & .. & .. & .. & .. & .. \\
\hline -. & .. & .. &.. & .. & .. & .. & .. & .. & .. & .. & .. & .. & .. & .. & .. &.. \\
\hline .. & .. & -. &.. & $\cdot \cdot$ & .. & .. & -. & .. & .. & $x$ &.. & .. &.. & $x$ & .. & $x$ \\
\hline$x$ & .. & .. &.. & .. & -. &.. & .. & .. & .. & .. &.. & .. &.. &.. & .. &.. \\
\hline -. & .. &.$\cdot$ & -. & .. & $\times$ & $x$ & -. & $\times$ & .. &.. & .. & .. & .. & .. & $\times$ & .. \\
\hline .. & -. & .. & -. & .. & $x$ & $x$ & .. & .. & .. & .. & .. & .. & .. & .. & .. &.. \\
\hline -. & $\cdot \cdot$ & $x$ & $\cdot \cdot$ & $x$ & .. &.. & .. & $x$ & .. &.. & .. & .. & .. & .. & -. &.. \\
\hline .. &.$\cdot$ & -. & .. & -. & -. & .. & .. & .. & .. &.. & .. & .. & .. & .. & .. & .. \\
\hline .. & .. & .. & $x$ & -. & .. & .. & .. & .. & -. & .. & $x$ & .. & .. & .. & .. & .. \\
\hline .. & $x$ & -. & $\times$ & $\cdot \cdot$ & -. & .. & $x$ & .. & $x$ & $x$ & $\cdot \cdot$ & .. & -. & -. & -. & $x$ \\
\hline .. & .. & .. & $x$ & $x$ & $x$ & .. & .. & .. & .. & -. &.. & .. & .. & .. & .. & .. \\
\hline .. & $x$ & .. & $x$ & .- & $x$ & .. & -. & .. & .. & $x$ &.. & .. & .. & $x$ & -. & $x$ \\
\hline .. &.. & .. & .. & .. & -. & .. & .. & .. & .. & .. & .. & .. & .. & .. & .. & .. \\
\hline -. &.. & .. & .. &.. & $\times$ & .. & .. & .. & .. & .. & .. & .. & .. & .. & .. &.. \\
\hline -. & $\cdot$. & -. & $\cdot \cdot$ & $x$ & $\times$ & $\cdot$. & -. & .. & .. & .. & .. & .. & -. & .. & $\cdot \cdot$ &.. \\
\hline .. & .. & .. & .. & .. & .. & $x$ & .. & $x$ & .. & .. & .. & .. & .. & .. & .. & .. \\
\hline -. & .. & .. & .. & .. & $x$ & $x$ & .. & .. & .. &.. & .. & .. & .. & .. & .. &.. \\
\hline .. & .. & .. & .. & $x$ & $x$ & .. & .. & .. & .. &.. & .. & .. & -. & .. & .. &.. \\
\hline .* & -. & .. & .. & $\cdot \cdot$ & -. & .. & -. & $x$ & .. & -. & -. & .. & -. & .. & -. & .. \\
\hline$\cdot \cdot$ & $\cdot \cdot$ & $\cdot$. & $\cdot \cdot$ & -. & .. & .. & .. &.. & .. & -- & .. & $x$ & $x$ & .. & $x$ &.. \\
\hline .- & .. & .. & .. & .. & .. & .. & .. & .. & .. & .. & .. & .. & .. & .. & .. & .. \\
\hline .. & $x$ & .. & -. & .. & .. & .. & -. & .. & .. & -. &.. & .. &.. & .. & -. & .. \\
\hline
\end{tabular}


in Arizona (Skipp, 1969), the Escabrosa Limestone of southeastern Arizona (Armstrong and Mamet, 1978), and the Dawn and part of the Anchor Limestone Member of the Monte Cristo Limestone in southern Arizona (Brenckle, 1970; Mamet and Skipp, 1970).

\section{FACIES AND ENVIRONMENTS OF DEPOSITION}

The thin-bedded echinoderm-bryozoan-brachiopod packstones of the Kinkead Spring Limestone indicate deposition on an open platform marine environment. The ooid algae-foraminifer packstones to grainstones indicate a shallow, shoaling water environment of deposition.

\section{ANTELOPE RANGE FORMATION (NEW NAME)}

The Antelope Range Formation is here named from outcrops in sec. 22 , T. 16 N., R. 51 E., in the northern Antelope Range. It is also recognized west of hill 7731 and elsewhere in the southern Fish Creek Range. Its thickness is unknown for, although the basal contact is present in many places, the upper part is faulted or eroded out.

\section{LITHOLOGY}

Because of structural complications and limited exposures, the precise sequence of rock types and internal variation is uncertain. Where the base is exposed there is a sequence of perhaps as much as $30 \mathrm{~m}$ of dark-yellowish-orange to light-brown-weathering sandstone. The sandstones are quite similar to those of the Diamond Peak Formation, although in the Diamond Peak the ratio of chert to quartz and feldspar is high and the grains are tightly sutured. Most beds contain grains that range from very fine to coarse, and range from angular to rounded. Other beds are better sorted and contain grains that are subequant and well rounded.

There is considerable variation in quartz plus feldspar grains versus those of chert and of lithic clasts. Quartz plus feldspar makes up between an estimated 25 and 75 percent of the rock (mainly more than 50 percent), chert between 5 and 35 percent, and lithic clasts from 20 to 40 percent. Quartz is considerably more common than the feldspar, which is estimated at 5 to 10 percent of the total quartz plus feldspar. The lithic clasts are mainly derived from shale. Blebs of ferruginous material are scattered through most of the sandstone and are probably the source of the dark-yellowish-orange color. The sandstone here and there contains pebbly zones. Sparse interstitial calcite is present in places. The rock above the sandstone is mainly a silty shale or very thin bedded, platy siltstone, both of which are olive gray and slope forming. Medium-gray shale is also present locally. A tan-colored limestone, found about 1-1/2 km north of hill 7473 in the southern Fish Creek Range, may be part of the Antelope Range Formation.

In the northern Antelope Range, the contact of the Antelope Range Formation with the Kinkead Spring Limestone is represented by a sharp change from medium-gray detrital limestone, below, to moderate yellowish-orange sandstone, above. In the southern Fish Creek Range, the Antelope Range Formation rests unconformably on the Devils Gate Limestone-there the Joana Limestone, the Pilot Shale, and an indeterminate amount of the upper part of the Devils Gate have been removed by pre-Antelope Range Formation erosion. Geologic mapping by Hose (unpub. data) suggests that the contact may be a thrust fault of unknown age, rather than a depositional contact.

\section{BIOSTRATIGRAPHY}

Calcareous concretions from a silty shale in the northern Antelope Range yielded the following conodonts: Palmatolepis of the P. glabra Ulrich and Bassler group, Polygnathus cf. P. inornatus Branson, and Siphonodella isosticha Cooper. Similar mixed Devonian and Mississippian conodonts were found in the southern Fish Creek Range in limestone beds that are believed to belong in the Antelope Range Formation. Because of poor exposures, however, we are not entirely certain of this interpretation. In any case, the Antelope Range Formation is considered Mississippian and must be Osagean or younger because of its stratigraphic position above the Osagean Kinkead Spring Limestone. Aside from scattered sparse plant remains found in some of the sandstone beds, no megafossils have been found. Samples collected for pollen and spores (USGS nos. D5174, D5175, D5176, D5181) yielded palynomorphs that R. H. Tschudy (written commun., 1974) believes to represent the taxa Leiosphaera and Tasmanites. Tasmanites, and to a lesser degree Leio sphaera, are common in the Devonian, but in the absence of other taxa, could represent Lower Mississippian.

Tasmanites and Leiosphaera are probably algal cysts representing marine deposition. The above samples yielded 2 specimens of trilete spores. Such spores are common to nearshore marine and nonmarine deposition sites. My best estimate is that if these fossils are in place and not redeposited these samples represent the Devonian or Lower Mississippian. Mamet found in thin section in a pelletoidal spiculite from the lower part of the Antelope Range Formation, Archaesphaera sp., Calcisphaera laevis Williamson, Parathurammina sp., and Vicinesphaera sp. He concluded that the youngest possible age was middle Carboniferous and the probable age was early Carboniferous. 
If the sandstone-shale sequence of the northern Antelope Range (Antelope Range Formation) is indeed correlative genetically or otherwise with the rocks of near identity in the southern Fish Creek Range from whence these samples were obtained, then the Fish Creek Range sequence of the Antelope Range Formation must also be Osagean or younger Mississippian.

Despite the great similarity of the Antelope Range Formation in the northern Antelope Range to the sandstone and shale sequence in the Fish Creek Range, there is no absolute certainty that they are precisely equivalent temporarily. Aside from the great lithic similarity, the other most important criterion for correlation is the profound unconformity at the base of the sandstone-shale sequence in both the Antelope and Fish Creek Ranges.

\section{DEPOSITIONAL ENVIRONMENT}

The presence of plant remains in the sandstone and nearshore marine and nonmarine spores in the silty shale suggest that the sequence accumulated in an estuarine or deltaic environment.

\section{DISCUSSION}

The Devonian and Mississippian strata of the northern Antelope Range have some degree of similarity to the sequence in the southern Fish Creek Range about $10 \mathrm{~km}$ to the east (fig. 7). However, there are also some noteworthy differences in the section. Some of the contrasts are normal stratigraphic and geographic variations, whereas others undoubtedly result from telescoping along thrust faults. Figure 7 shows that the Beacon Peak Dolomite and McColley Canyon Formation are present in both ranges. The Sentinel Mountain Dolomite [of the southern Diamond Mountains] is present in the southern Fish Creek Range but absent in the Antelope Range. The Woodpecker Limestone, which lies above the Sentinel Mountain Dolomite in the southern Diamond Mountains and which should be present in the subsurface of southern Fish Creek Range, is partly equivalent to the Denay Limestone.
The South Hill Sandstone, which crops out in small fault blocks in the southern Fish Creek Range, is not present in the Antelope Range. The Bay State Dolomite of the southern Fish Creek Range is temporally correlative with the lower part of the Fenstermaker Wash Formation but differs from it in that it is finer grained. The Devils Gate Limestone is lime mudstone whereas the Fenstermaker Wash is mainly brachiopodechinoderm-peloid packstone and grainstone. Two Mississippian units of the northern Antelope Range, the Davis Spring Formation and the Kinkead Spring Limestone, are unconformably overlapped by the Antelope Range Formation and are altogether absent in the Fish Creek Range and have no known lithic counterpart east of the Fish Creek Range. The Kinkead Spring Limestone is recognized to the southwest in the Dobbin Summit area of the Monitor Range.

In the northern part of the Cockalorum Wash quadrangle in the southern Fish Creek Range, the Antelope Range Formation rests on the Devils Gate Limestone. There the upper part of the Devils Gate and the overlying Chainman Shale, Joana Limestone, and Pilot Shale are absent. However, in the more southerly parts of the Fish Creek Range a Middle Devonian limestone unit plus a unit that greatly resembles the Pilot Shale and which is the same age, is present. The combined limestone and shale were included with other strata in the Cockalorum Wash Formation by Merriam (1973).

The Antelope Range Formation occurs in both the northern Antelope and southern Fish Creek Ranges. In the Fish Creek Range it appears to be overthrust by an unnamed Mississippian unit quite different from any unit heretofore described. It is a sequence of lightyellowish-gray siliceous mudstone, siltstone, claystone, and some chert, that contains limestone beds of Osagean age low in the section (A. K. Armstrong, written commun., 1977). This siliceous Mississippian formation is in turn overthrust by an incomplete siliceous mudstone sequence of Late Devonian age assigned to the Woodruff Formation. 


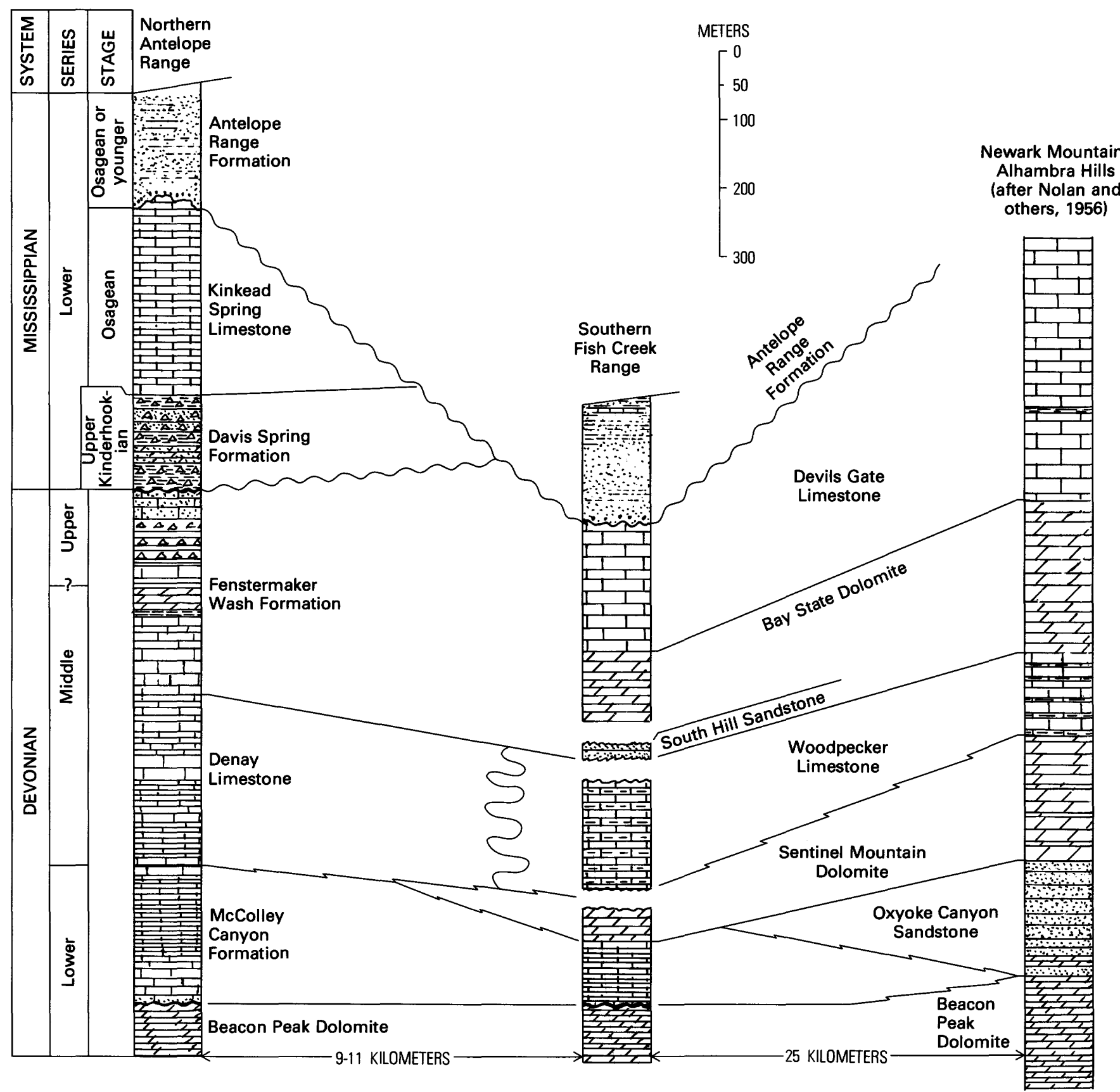

FiguRE 7.-Correlation of Devonian and Mississippian rocks in northern Antelope Range, southern Fish Creek Range, and Newark Mountains. (See figure 5 for explanation of symbols.) 


\section{REFERENCES CITED}

Armstrong, A. K., and Mamet, B. L., 1977, Carboniferous microfacies, microfossils, and corals, Lisburne Group, Artic Alaska: U.S. Geological Survey Professional Paper 849, $144 \mathrm{p}$.

— 1978, The Mississippian system of southwestern New Mexico and southeastern Arizona: New Mexico Geological Society Guidebook, 29th Field Conference, p. 183-192.

Bamber, E. W., and Mamet, B. L., 1978, Carboniferous biostratigraphy and correlation, northeastern British Columbia and southwestern District of Mackenzie: Geological Survey of Canada Bulletin 266, $65 \mathrm{p}$.

Brenckle, P. L., 1970, Smaller Mississippian and Lower Pennsylvanian calcareous foraminifera from Nevada: Cushman Foundation for Foraminiferal Research Special Publication no. 11, 82 p.

Carlisle, D., Murphy, M. A., Nelson, C. A., and Winterer, E. L., 1957, Devonian stratigraphy of Sulphur Springs and Pinyon Canyon Range, Nevada: American Association of Petroleum Geologists Bulletin, v. 41, p. 2175-2191.

Carls, Peter, and Gandl, Josef, 1969, Stratigraphie und conodonten des Unter-Devons der Ostlichern Iberischen Ketten (NE-Spanien): Neues Jahrbuch für Geologie und Paläontologie Abhandlungen, v. 132 , p. 155-218.

Folk, R. L., and Land, L. S., 1975, Mg/Ca ratio and salinity: Two controls over crystallization of dolomite: American Association of $\mathrm{Pe}$ troleum Geologists Bulletin, v. 59, no. 1, p. 60-68.

Glenister, B. F., Klapper, Gilbert, and Chauff, K. M., 1976, Conodont pearls?: Science, v. 193, p. 571-573.

Johnson, J. G., 1962, Lower Devonian-Middle Devonian boundary in central Nevada: American Association of Petroleum Geologists Bulletin, v. 46 , no. 4 , p. $542-546$.

1966, Middle Devonian brachiopods from the Roberts Mountains, central Nevada: Paleontology, v. 9, p. 152-181, pls. 23-27.

Klapper, Gilbert, 1977, Lower and Middle Devonian conodont sequence in central Nevada, in Murphy, M. A., Berry, W. B. N., and Sandberg, C. A., eds., Western North America-Devonian: Riverside, California University, Riverside Campus Museum Contribution No. 4, p. 33-54.

Mamet, B. L., 1976, An atlas of microfacies in Carboniferous carbonates of the Canadian Cordillera: Geological Survey of Canada Bulletin 255, $131 \mathrm{p}$.

Mamet, B. L., and Skipp, B. A., 1970, Lower carboniferous calcareous foraminifera; preliminary zonation and stratigraphic implications for the Mississippian of North America: Congresse Internationale Stratigraphie et Géologie Carbonifère, 6th, Sheffield, 1967, Comptes Rendus, v. 3, p. 1129-1146.

Matti, Johathan, 1979, Depositional history of middle Paleozoic carbonate rocks deposited at an ancient continental margin, central Nevada: Stanford, Calif., Stanford University, Ph. D. thesis, 485 p.

Merriam, C. W., 1973, Middle Devonian rugose corals of the central Great Basin: U.S. Geological Survey Professional Paper 799, 53 p.

Nolan, T. B., Merriam, C. W., and Williams, J. S., 1956, The stratigraphic section in the vicinity of Eureka, Nevada: U.S. Geological Survey Professional Paper 276, $77 \mathrm{p}$.

Osmond, J. S., 1954, Dolomites in the Silurian and Devonian of eastcentral Nevada: American Association of Petroleum Geologists Bulletin, v. 38, no. 9, p. 1911-1956.

Sandberg, C. A., and Gutschick, R. C., 1978, Biostratigrahic guide to Upper Devonian and Mississippian rocks along the Wasatch front and Cordilleran hingeline, Utah: U.S. Geological Survey Open-File Report 78-351, $52 \mathrm{p}$.

Sandberg, C. A., and Poole, F. G., 1977, Conodont biostratigraphy and depositional complexes of Upper Devonian cratonic-platform and continental-shelf rocks in the western United States, in Murphy, M. A., Berry, W. B. N., and Sandberg, C. A., eds., Western North America-Devonian: Riverside, California University, Riverside Campus Museum Contribution 4, p. 144-182.

Sando, W. J., Mamet, B. L., and Dutro, J. T., Jr., 1969, Carboniferous megafaunal and microfaunal zonation in the northern Cordillera of the United States: U.S. Geological Survey Professional Paper 613-E, p. E7-E29.

Skipp, B., 1969, Foraminifera, in McKee, E. D., and Gutschick, R. C. eds., History of the Redwall Limestone of northern Arizona, Chapter 5: Geological Society of America Memoir 114, p. 173-255.

Weddige, Karsten, and Ziegler, Willi, 1976, The significance of Icriodus-Polygnathus ratios in limestones from the type Eifelian, Germany: Geological Association of Canada Special Paper 15, p. 187-199.

Ziegler, Willi, 1966, Eine Verfeinerung der Conodontengliederung an der Grenze Mittel-/Oberdevon: Fortschrifte in der Geologie von Rheinland und Westfalen, v. 9, p. 647-676.

Ziegler, Willi, Klapper, Gilbert, and Johnson, J. G., 1976, Redefinition and subdivision of the varcus Zone (Conodonts, Middle-?Upper Devonian) in Europe and North America: Geologica et Paleontologia, v. 10, p. 109-140. 



\section{INDEX}

[Italic page numbers indicate both major references and descriptions]

Alhambra Hills, 9

Ancryodella buckeyensis, 10; pl. 8

Antelope Range, 15

Antelope Range Formation, 1, 14

Antelope Valley Limestone, 13; pl. 8

Archaesphaera sp., 14

Asphaltinella sp., 12

asymmetricus Subzone, Polygnathus, 10

australis Zone, Tortodus kockelianus, 9

Bay State Dolomite, 9, 15

Beacon Peak Dolomite, 1, 5, 15

beckmanni, Pseudoneotodus, 5

brachiopods, 8,9

Brunsiina sp., 12

bryozoans, 9

buckeyensis, Ancryodella, 10; pl. 8

Calcisphaera laevis, 12, 14

$$
\text { sp., } 12
$$

celtibericus, Icriodus huddlei, 7, 8; pl. 7

Chainman Shale, 15

Cockalorum Wash Formation, 15

Coleodus sp., 13; pl. 8

Columbiapora johnsoni, 12

$$
\text { sp., } 12
$$

communis, Polygnathus, 10, 13; pl. 8

Conodonts, 1, 7, 8, 10, 12, 13, 14; pls. 7, 8

Corals, 8,9

corniger, Icriodus, 8; pl. 7

costatus costatus Zone, Polygnathus, 9

costatus Zone, Polygnathus,

curvicauda, Icriodus huddlei, 7

Davis Spring Formation, 1, 10, 15; pls. 6, 8

decorosus, Polygnathus, 10; pl. 8

dehiscens, Polygnathus, 8

Zone, Polygnathus, 7

delicata, Kamaena, 12

delicatus, Gnathodus, 11, 13

Denay Limestone, $1,8,15$; pl. 3

Denay Valley, 8

Devils Gate Limestone, $8,14,15$

Diamond Mountains, 9, 15

Diamond Peak Formation, 14

duplicata, Siphonodella, 13; pl. 8

Earlandia sp., 12

Egan Range, 5

Eognathodus sulcatus, 7 sulcatus sulcatus Zone, 7

Eovolutina sp., 12

excavata, Ozarkodina, 7

exigua philipi, Pandorinellina, 7; pl. 7

Fenstermaker Wash Formation, 1, 9, 15; pls. 4, 5, 82

Fish Creek Range, 5, 14, 15

Foraminifers, 13

Gastropods, 5

gigas Subzone, Palmatolepis, 10 glabra, Palmatolepis, 11, 13, 14; pl. 8

Glomospiranella sp., 12

Gnathodus delicatus, 10, 13 punctatus, 11,$13 ;$ pl. 8

Grays Canyon Limestone Member, 5

gronbergi, Polygnathus, 7, 8; pl. 7

Zone, Polygnathus, 8

Halysites, 5

hassi, Palmatolepis, 10; pl. 8

huddlei, Icriodus, pl. 7

celtibericus, Icriodus, 7, 8; pl. 7

curvicauda, Icriodus, 7
Icriodus, 7; pl. 8

corniger, 8; pl. 7

huddlei, pl. 7

celtibericus, 7,$8 ;$ pl. 7

curvicauda, 7

symmetricus, $10 ;$ pl. 8

inornatus, Polygnathus, 14

insita, Pandorinellina, 10; pl. 8

Introduction, 1

isosticha, Siphonodella, 11, 13, 14;

pl. 8,3

Issinella sp., 12

Joana Limestone, 14, 15

johnsoni, Columbiapora, 12

Ozarkodina, 5, 7

Kamaena sp., 12

Kamaena delicata, 12

Kamaenella sp., 12

Kinkead Spring Limestone, 1, 12; pls. 6, 8

kockelianus, Tortodus, 9

Tortodus kockelianus, 8, 9; pl. 7

australis Zone, Tortodus, 9

kockelianus, Tortodus, 8, 9; pl. 7

Zone, Tortodus, 9

Zone, Tortodus kockelianus, 9

laevis, Calcisphaera, 12, 14

Iahuseni, Palaeoberesella, 12

Latiendothyra sp., 12

Leiosphaera, 14

linguiformis, Polygnathus linguiformis, 9

linguiformis, Polygnathus, 9

Lone Mountain Dolomite, 5

McColley Canyon Formation, 1, 5, 15; pls. 1, 2, 5

miae, Pandorinellina steinhornensis, 7, 8; pl. 7

Moravammina sp., 12

Nevada Formation, 5

Newark Mountain, 9

Ninemile Canyon, 12, 4

norrisi, Polygnathus, 10; pl. 8

Nostocites sp., 12

Nowakia sp., 8, 9

Ozarkodina, D Zone, 7

excavata, 7

johnsoni, 5,7

remscheidensis, 5

Pahranagat Range, 5

Palaeoberesella lahuseni, 12 sp., 12

Paleocyclus sp., 5

Palmatolepis gigas Subzone, 10

glabra, 11, 13, 14; pl. 8

hassi, $10 ;$ pl. 8

perlobata, pl. 8

proversa, 10

Pandorinellina, 7

exigua philipi, 7; pl. 7

insita, 10 ; pl. 8

steinhornensis miae, 7, 8; pl. 7

Parathurammina sp., 12, 14

parawebbi, Polygnathus, 8, 9, 10; pls. 7, 8

Pedavis pesavis Zone, 5,7

Pekiskopora sp., 12

perlobata, Palmatolepis, pl. 8

pesavis Zone, Pedavis, 5,7

philipi, Pandorinellina exigua, 7 ;

$$
\text { pl. 7, } 5
$$

Pilot Shale, 14, 15

Polygnathus, 7, 8

asymmetricus Subzone, 10
Polygnathus -Continued

communis, 11, 13; pl. 8

costatus costatus Zone, 9

decorosus, 10; pl. 8

dehiscens, 7,8

Zone, 7

gronbergi, 7, 8; pl. 7

Zone, 8

inornatus, 14

linguiformis linguiformis, 9

norrisi, 10; pl. 8

parawebbi, $8,9,10$; pls. 7,8

robusticostatus, 9

semicostatus, 11, 13; pl. 8

serotinus Zone, 8

trigonicus, 9 ; pl. 7

varcus, pl. 8

Subzone, 10

Zone, 9,10

primaeva, Septaglomospiranella, 12

Proninella sp., 12

proversa, Palmatolepis, 10

Pseudoneotodus beckmanni, 5

punctatus, Gnathodus, 11, 13; pl. 8

Receptaculites sp., 9

Rectoseptaglomosptranella sp., 12,13

remscheidensis, Ozarkodina, 5

Roberts Mountains, 8

robusticostatus, Polygnathus, 9

semicostatus, Polygnathus, 11, 13; pl. 8

Sentinal Mountain Dolomite, 9, 14

Septabrunsiina sp., 12, 13

Septaglomospiranella primaeva, 12

sp., 12

Septatournayella sp., 12

serotinus Zone, Polygnathus, 8

Sevy Dolomite, 5

Simpson Park Mountains, 8

Siphonodella duplicata, 13; pl. 8

isosticha, 11, 13, 14; pl. 8

South Hill Sandstone, 15

Sphaeroporella sp., 12

Spinoendothyra sp., 12, 13

steinhornensis miae, Pandorinellina, 7, 8; pl. 7

Striatolina sp., 8, 9

sulcatus, Eognathodus, 7

sulcatus Zone, Eognathodus, 7

Zone, Eognathodus, 7

Sulphur Springs Range, 5

symmetricus, Icriodus, 10; pl. 8

Tasmanites sp., 14

Tentaculites sp., 8

Tortodus kockelianus, 9

kockelianus australis Zone, 9

kockelianus, 8,9 ; pl. 7

Zone, 9

trigonicus, Polygnathus, 9; pl. 7

tuberculata, Tuerendothyra, 12, 13

Tuberendothyra tuberculata, 12, 13 sp., 12

Upper Davis Spring, 10

varcus, Polygnathus, pl. 8 Subzone, Polygnathus, 10

Zone, Polygnathus, 9, 10

Vicinesphaera sp., 14

Willow Creek Canyon, 8

Woodpecker Limestone, 9, 15

Woodruff Formation, 15 



\section{PLATES 1-8}

[Contact photographs of the plates in this report are available, at cost, from the U.S. Geological Survey Library, Federal Center, Denver, Colorado 80225] 


\section{PLATE 1}

Figures 1-6. McColley Canyon Formation

1,2 , 3. Specimen $40 \mathrm{~m} ; 1$, plane-light photomicrograph of a pellet-brachiopod-echinoderm packstone; 2 , scanning electron micrograph of round object, possibly a calcisphere or an ostracode; interior is filled with $5-\mu \mathrm{m}$ calcite rhombs and intercrystalline clay minerals. Calcite surrounding shell is $10-20 \mu \mathrm{m}$ in size; some dolomite (D) is present. 3, Scanning electron micrograph of micrite matrix of the packstone, with 5 - to $10-\mu \mathrm{m}$ calcite rhombs and clay minerals between the calcite crystals.

4. Specimen $44 \mathrm{~m}$; scanning electron micrograph of a dolomitic-argillaceous packstone; euhedral rhombs of dolomite (D); abundant clay minerals are between the calcite crystals.

5. Specimen $75 \mathrm{~m}$; scanning electron micrograph of dolomitic-pellet packstone. The subhedral dolomite rhombs (D) are from a few to $30 \mu \mathrm{m}$ in size, matrix is 5- to $10 \cdot \mu \mathrm{m}$ calcite rhombs; lower right side shows a transverse section of a foliated brachiopod shell.

6. Specimen $98 \mathrm{~m}$; plane-light photomicrograph of pellet-calcisphere-dolomitic packstone. 

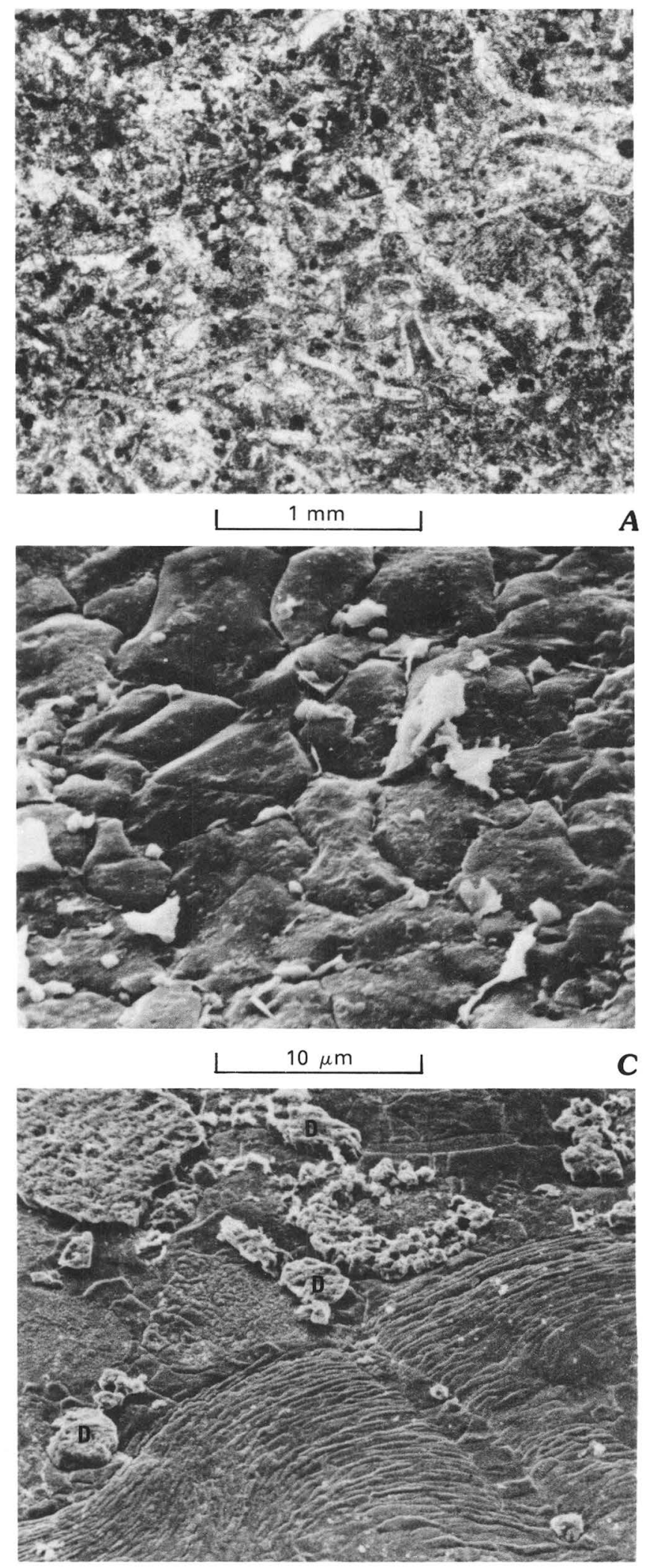

C

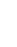
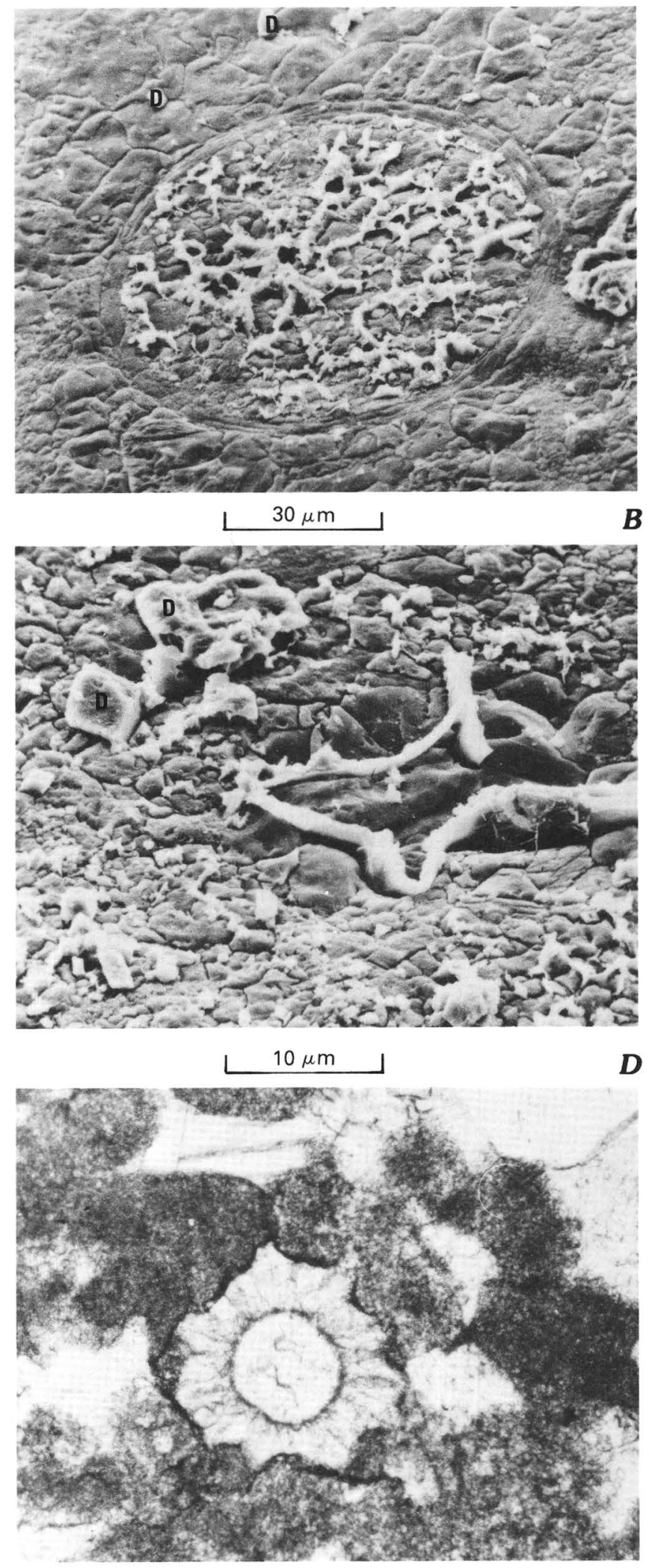

$20 \mu \mathrm{m}$ 


\section{PLATE 2}

FiguRES 1,2. McColley Canyon Formation

1. Specimen $112 \mathrm{~m}$; scanning electron micrograph of bryozoan packstone. Interiors of fossils are filled with a matrix of clay minerals and anhedral calcite rhombs. Some dolomite (D) is present.

2. Specimen $149 \mathrm{~m}$; scanning electron micrograph of insoluble residue sample from lime mudstone. Broken sponge spicule? preserved by dolomite crystals.

3-6. Denay Limestone

3, 4. Specimen $202 \mathrm{~m}$; 3, plane-light photomicrograph tentaculites-packstone; 4, scanning electron micrograph of argillaceous-dolomite-tentaculites wackestone; dolomite (D).

5. Specimen $288 \mathrm{~m}$; scanning electron micrograph of argillaceous-dolomitic brachiopod-pellet wackestone; dolomite (D) and intercrystalline clay minerals can be seen in a calcite micrite matrix.

6. Specimen $316 \mathrm{~m}$; scanning electron micrograph of dolomitic lime mudstone. A stylolite (lower left to upper right) is outlined by a slight increase in dolomite (D) rhombs. The rock is relatively free of clay minerals. 
GEOLOGICAL SURVEY

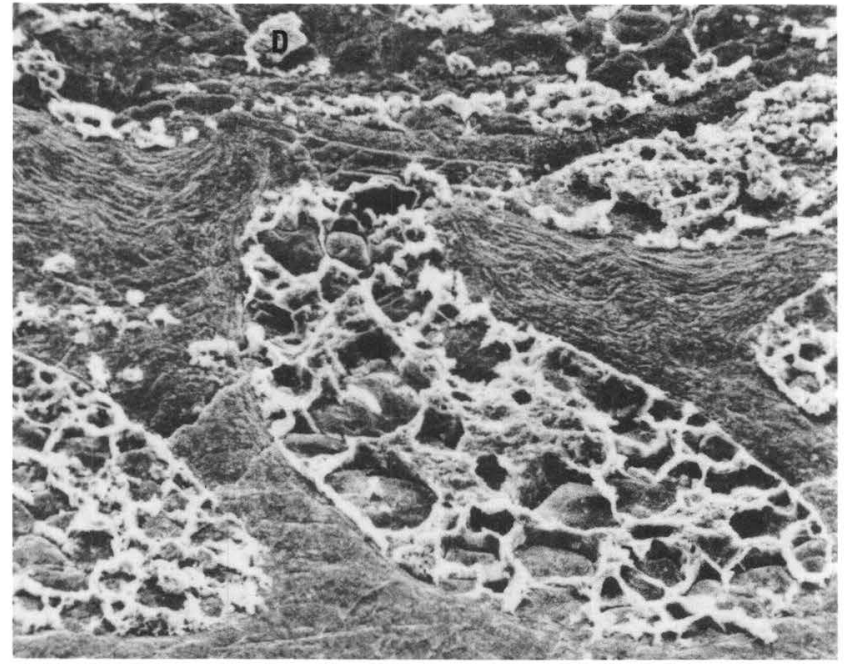

A

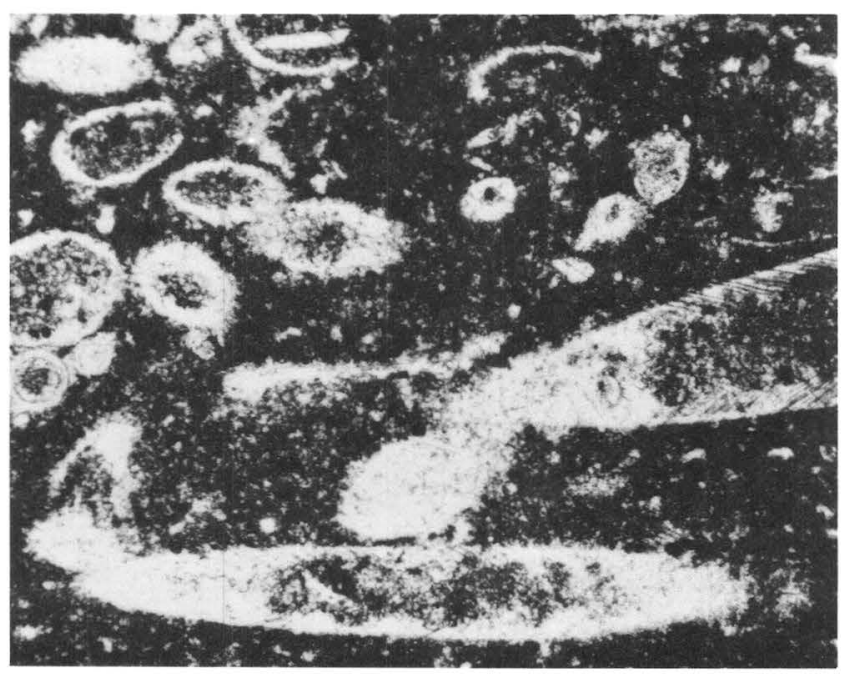

$1 \mathrm{~mm}$

C

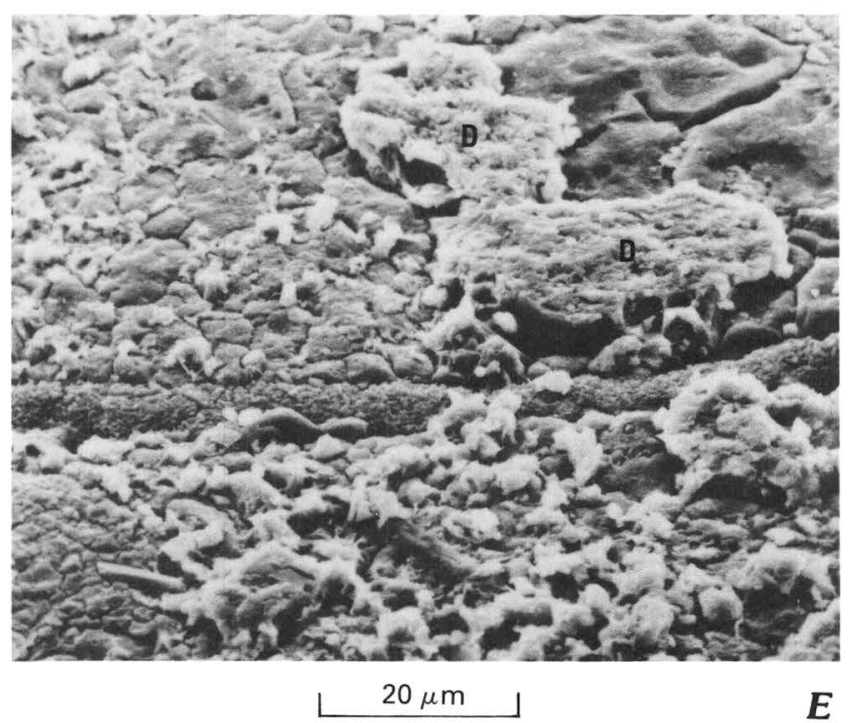

PROFESSIONAL PAPER 1182, PLATE 2

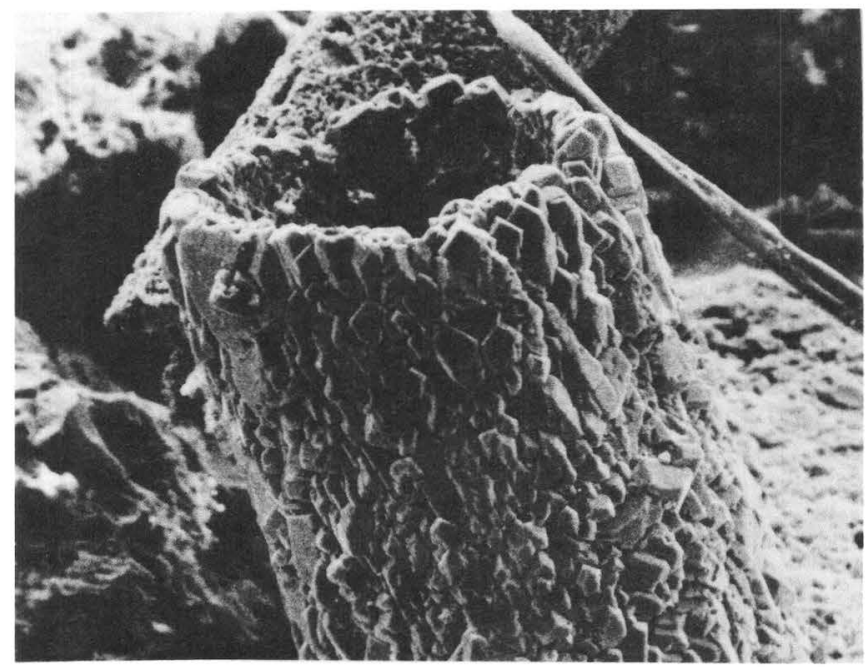

$100 \mu \mathrm{m}$

B
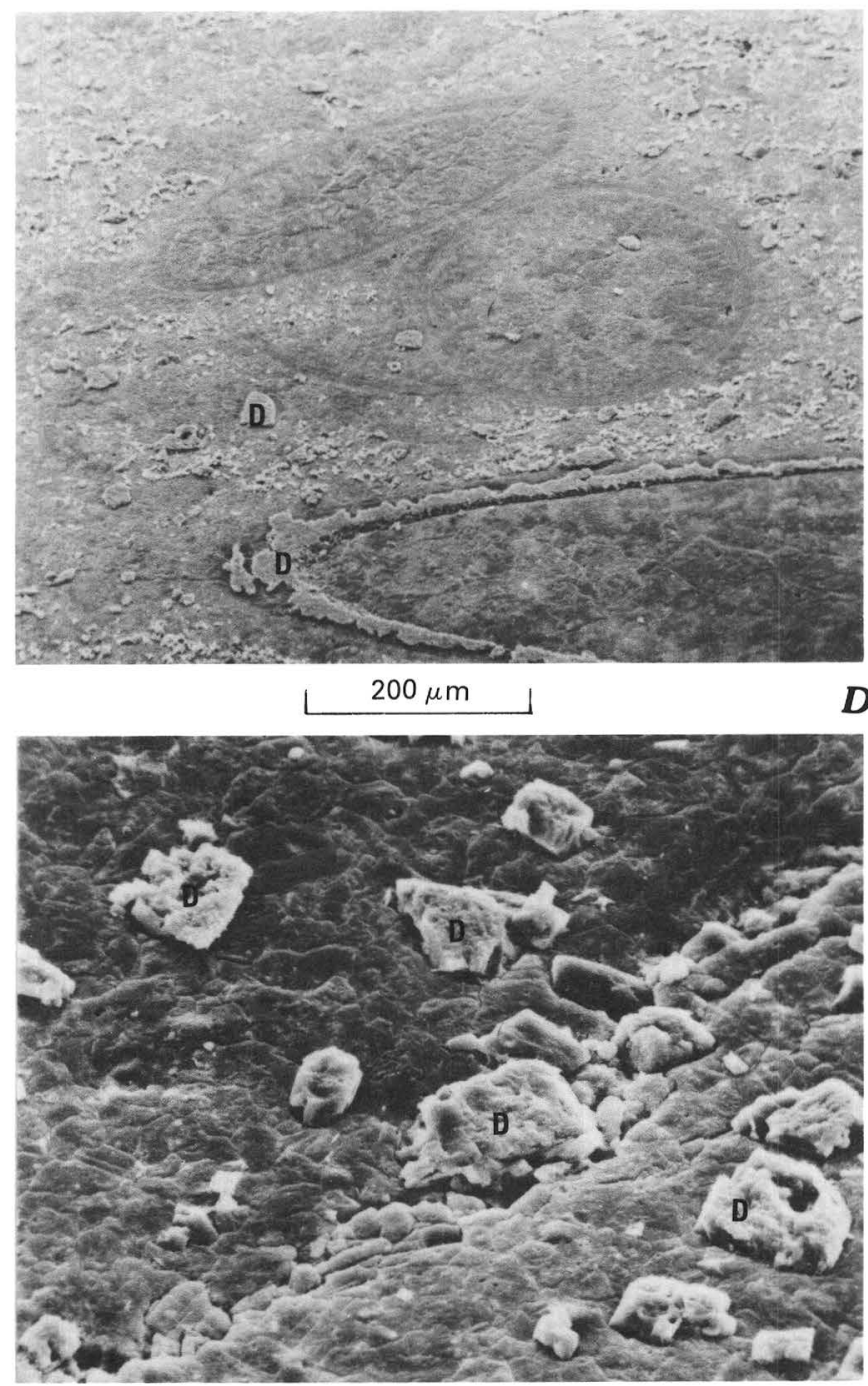

$30 \mu \mathrm{m}$

$\boldsymbol{F}$

McCOLLEY CANYON FORMATION, FIGURES $\boldsymbol{A}, \boldsymbol{B}$; AND DENAY LIMESTONE, FIGURES $\boldsymbol{C}-\boldsymbol{F}$ 


\section{PLATE 3}

Figures 1, 2. Denay Limestone

1. Specimen $410 \mathrm{~m} ; 1$, plane-light photomicrograph of a pellet-echinodermdolomitic packstone to grainstone. 2 , scanning electron micrograph, showing the peloids to contain 2- to $6 \cdot \mu \mathrm{m}$ anhedral calcite crystals and 5- to $10-\mu \mathrm{m}$ subhedral dolomite rhombs. The calcite matrix between the peloids is microspar from 30 to $70 \mu \mathrm{m}$ in size and is relatively free of dolomite

3-6. Fenstermaker Wash Formation

3,4. Specimen $451 \mathrm{~m}$; 3, plane-light photomicrograph, echinoderm-bryozoan packstone; 4 , scanning electron micrograph of a bryzoan fragment surrounded by microspar and sparry calcite rhombs 10 to $30 \mu \mathrm{m}$ in size.

5,6. Specimen $487 \mathrm{~m}$; 5 , plane-light photomicrograph of dolomitic-pellet-lump packstone; 6 , scanning electron micrograph showing subhedral dolomite rhombs (D) in a matrix of 4 - to $10-\mu$ calcite rombs. 
GEOLOGICAL SURVEY
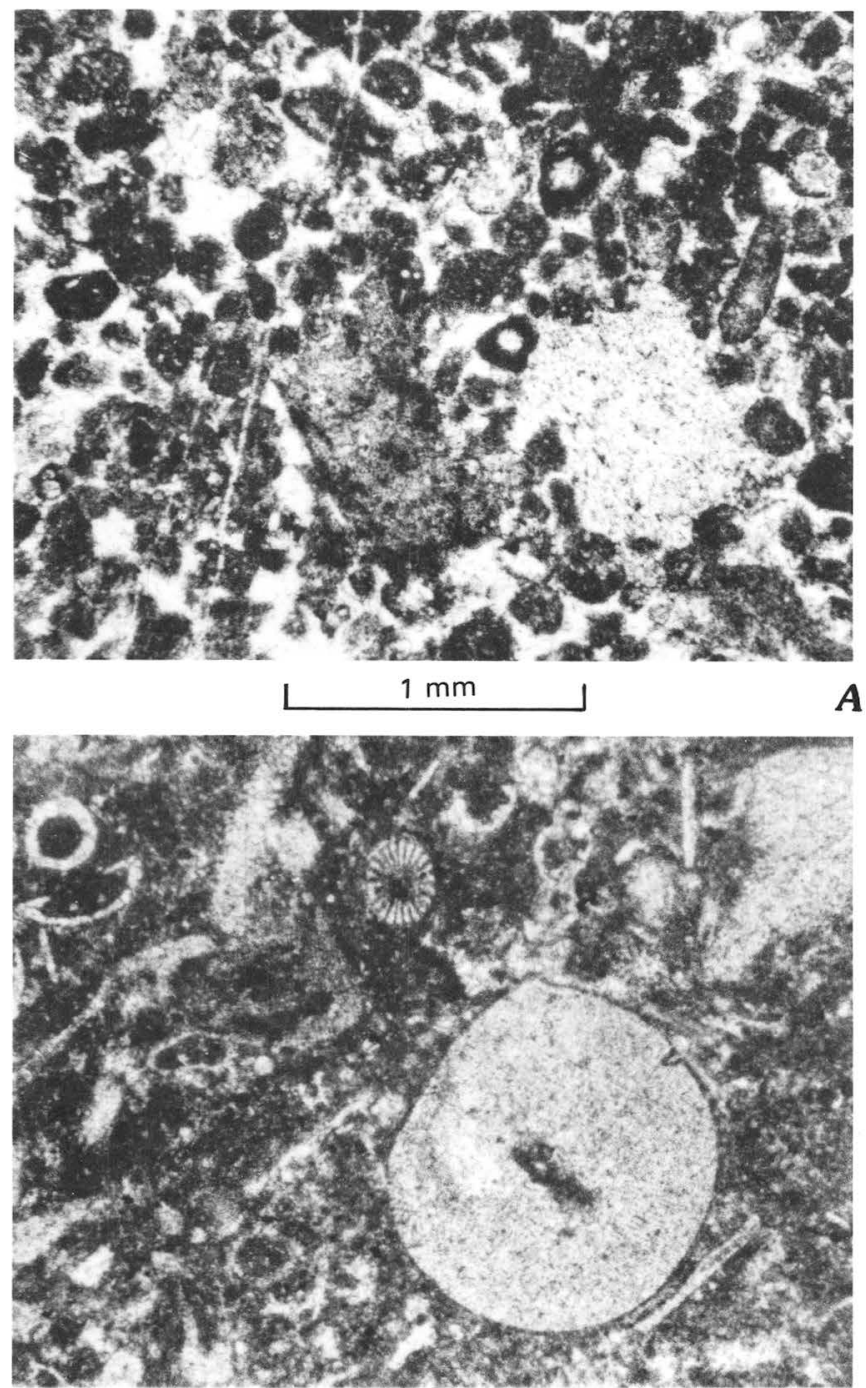
$1 \mathrm{~mm}$

C

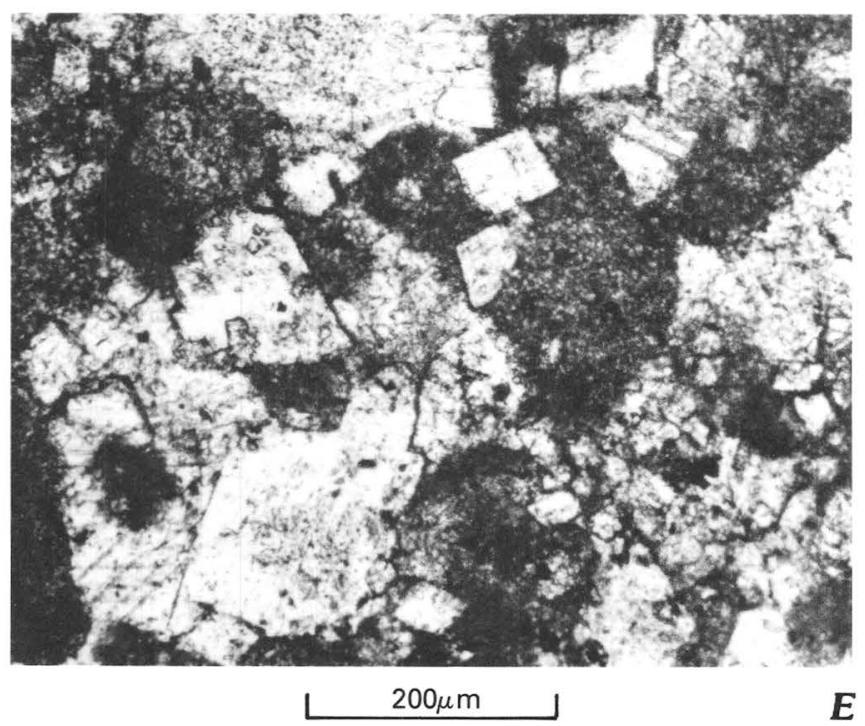

PROFESSIONAL PAPER 1182, PLATE 3
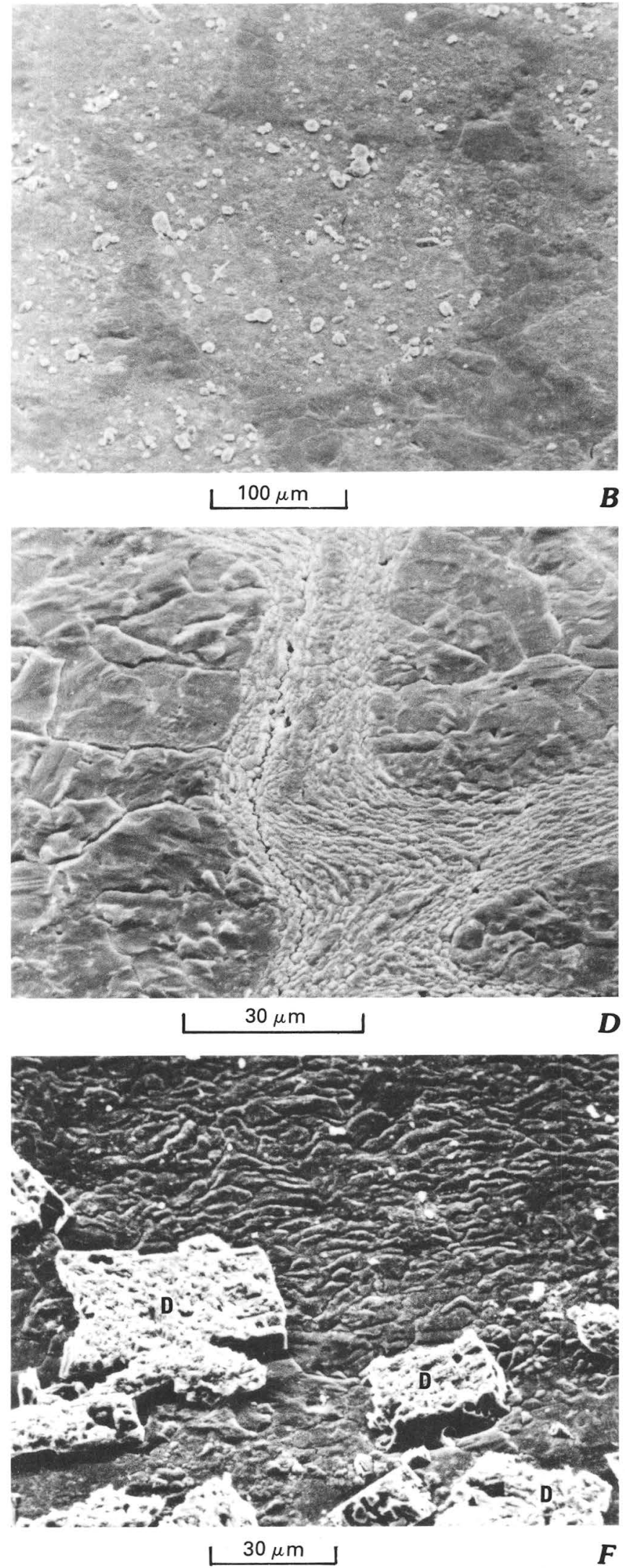

DENAY LIMESTONE, FIGURES $\boldsymbol{A}, \boldsymbol{B}$; AND FENSTERMAKER WASH FORMATION, FIGURES $\boldsymbol{C}-\boldsymbol{F}$ 


\section{PLATE 4}

Figures 1-6. Fenstermaker Wash Formation

1,2. Specimen $501 \mathrm{~m}$; 1, plane-light photomicrograph, arenaceous-dolomiticbryozoan packstone; 2 , scanning electron micrograph of a dolomite rhomb undergoing calcitification. Another is present in figure 1. Dolomite rhombs show irregular sides due to replacement by calcite.

3, 4. Specimen $526 \mathrm{~m}$; pellet-dolomitic packstone. 3, Plane-light photomicrograph of iron-rich calcite-zone dolomite (FD) rhombs. 4, scanning electron micrograph of an etched iron-rich calcite zone in a dolomite rhomb surrounded by a matrix of anhedral calcite grains 4 to $6 \mu \mathrm{m}$ in size.

5. Specimen $545 \mathrm{~m}$; arenaceous dolomite. Scanning electron micrograph of an etched surface of the dolomite, illustrating intercrystalline porosity and the euhedral dolomite rhombs.

6. Specimen $560 \mathrm{~m}$; scanning electron micrograph of dolomitic packstone showing range in dolomite size from $4-\mu$ to $100-\mu$ rhombs. 

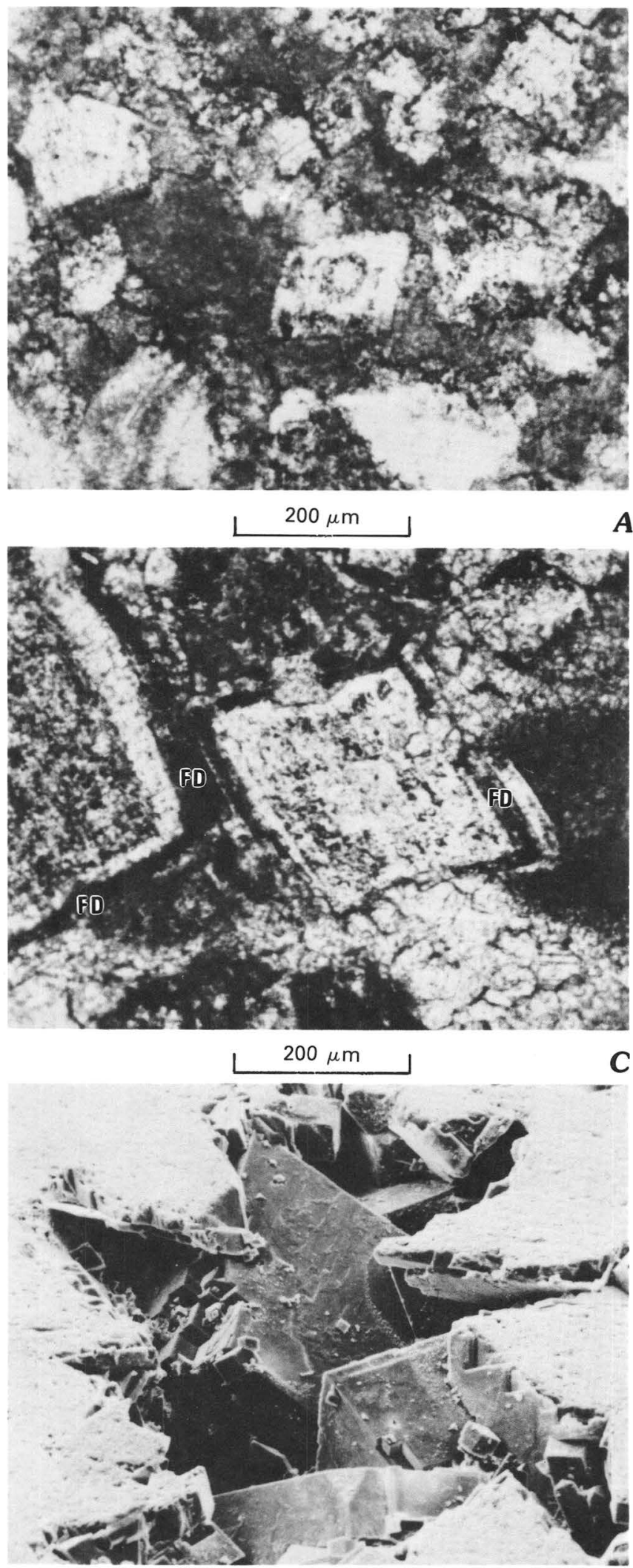

$100 \mu \mathrm{m}$

E
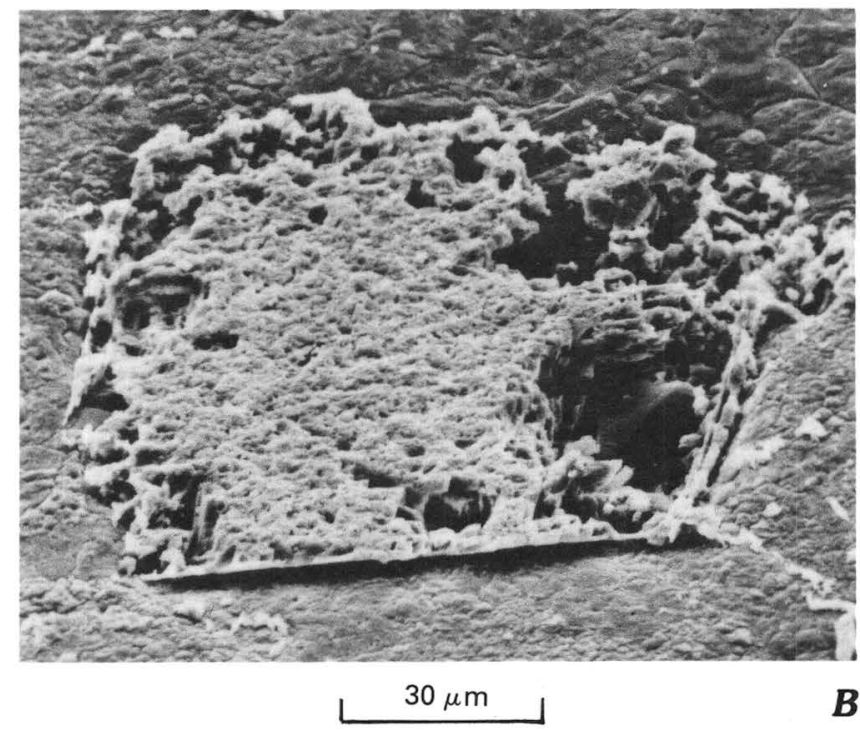

B
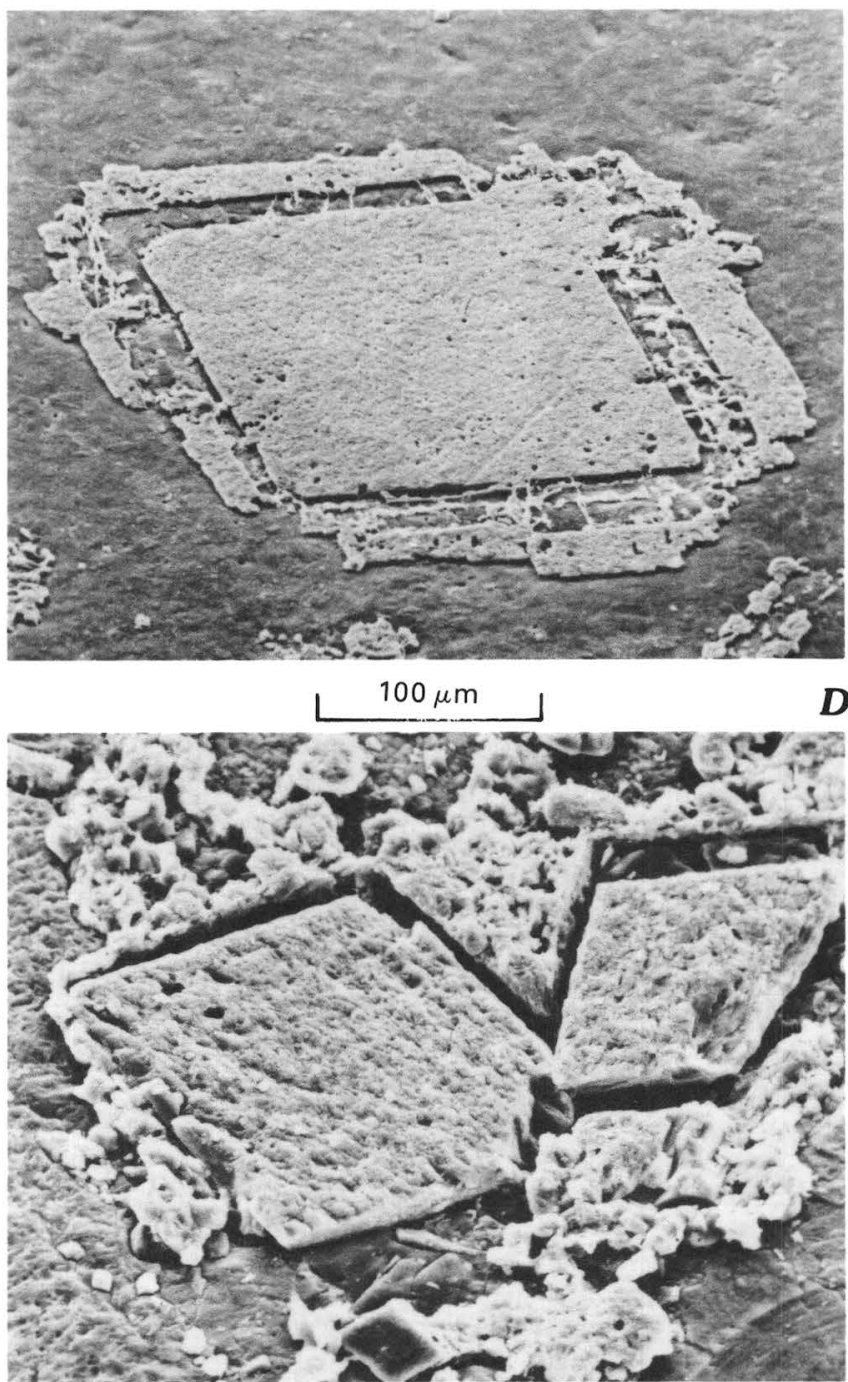

$30 \mu \mathrm{m}$ 


\section{PLATE 5}

Figures $\quad 1-5$. Fenstermaker Wash Formation

1,2. Specimen $596 \mathrm{~m} ; 1$, plane-light photomicrograph, peloid-mud lump grainstone, space between particles is filled by sparry calcite; some peloids show evidence of concentric lamellar patterns or ooid coatings. Fossil fragments are echinoderms and brachiopods. Large ooid in lower left corner has a sparry calcite center of nucleus, which probably was originally aragonite that was removed by leaching and replaced by calcite. 2 , Scanning electron micrograph of peloids made up of micrite-size calcite rhombs, $5 \mu \mathrm{m}$ or less in size; area between peloids is filled by large $(10$ to $50 \mu \mathrm{m})$ rhombs of calcite. White crystals in relief between calcite crystals are detrital clay minerals.

3, 4,5. Specimen $609 \mathrm{~m}$; 3, plane-light photomicrograph, peloid-calcisphere-lump packstone to grainstone. 4, 5, scanning electron micrographs. 4, Circular peloid contains impurities of clay minerals and dolomite rhombs. 5, Partial view of three peloids composed of micrite calcite rhombs with some clay minerals. Area between rhombs is filled by sparry calcite.

6. McColley Canyon Formation

6. Specimen $42 \mathrm{~m}$; scanning electron micrograph of the insoluble residue, rounded $400-$ to $500-\mu \mathrm{m}$ grains of quartz sand. Surfaces of grains have a chalcedony overgrowth that protruded into the space between calcite crystals. 

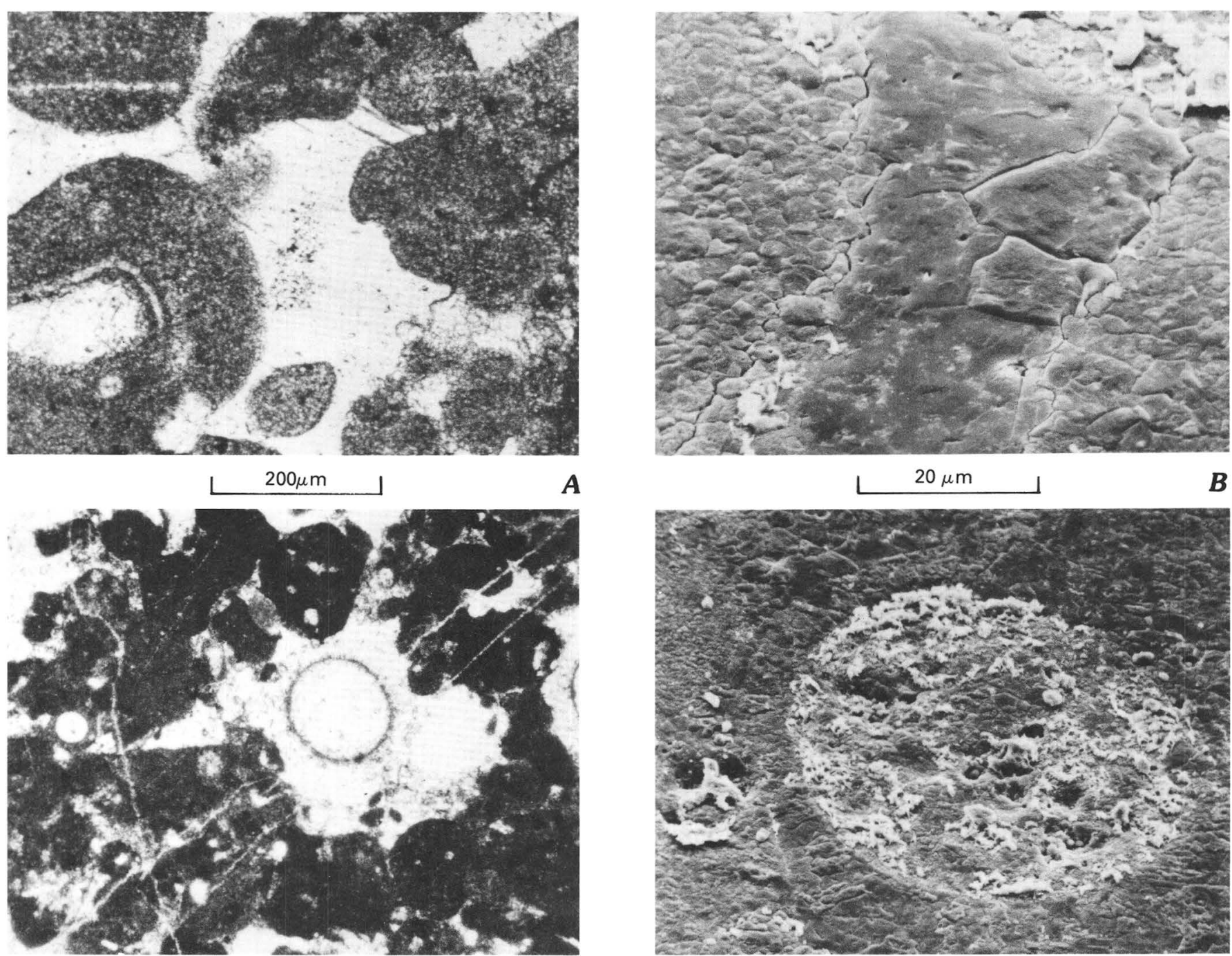

A
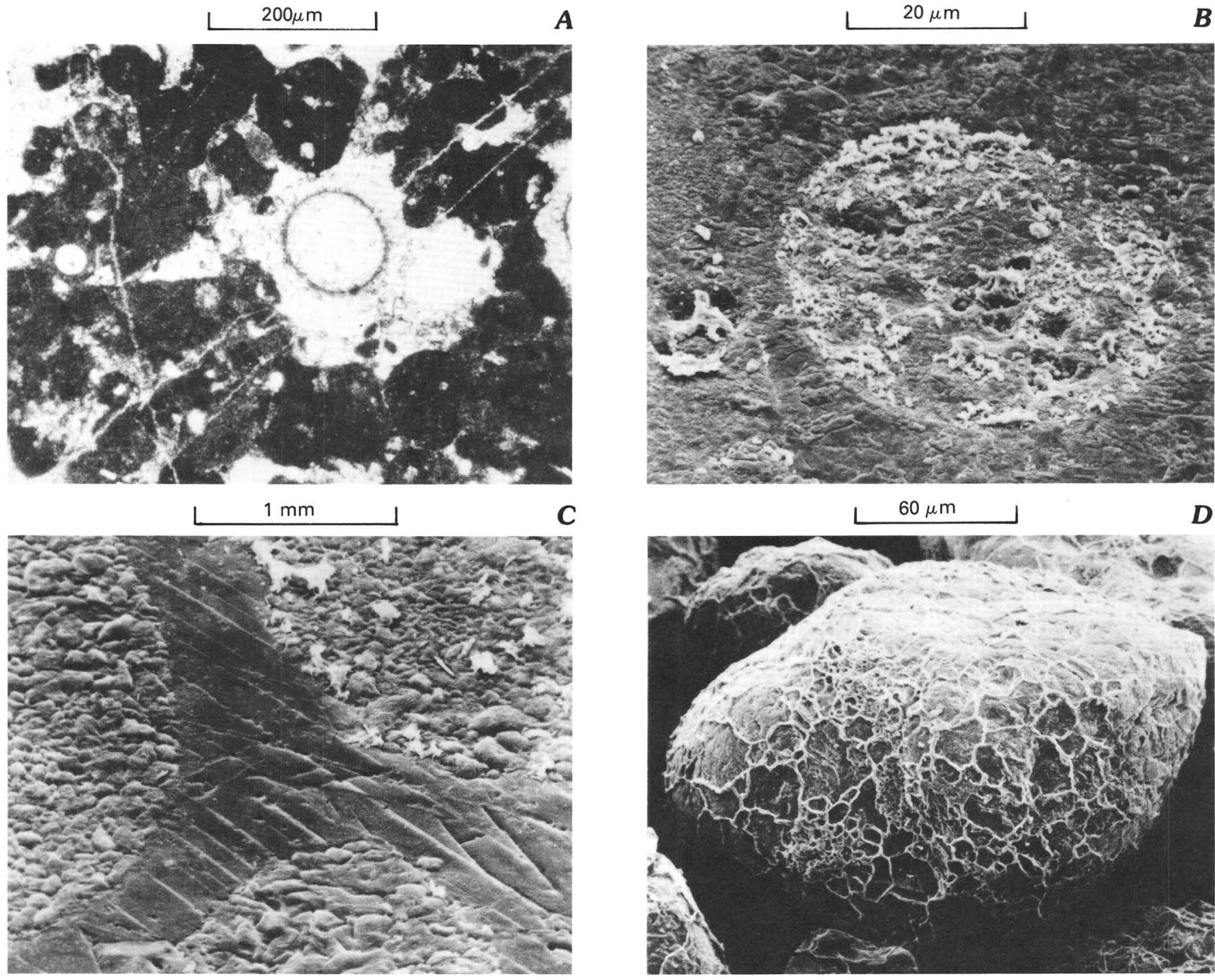

C

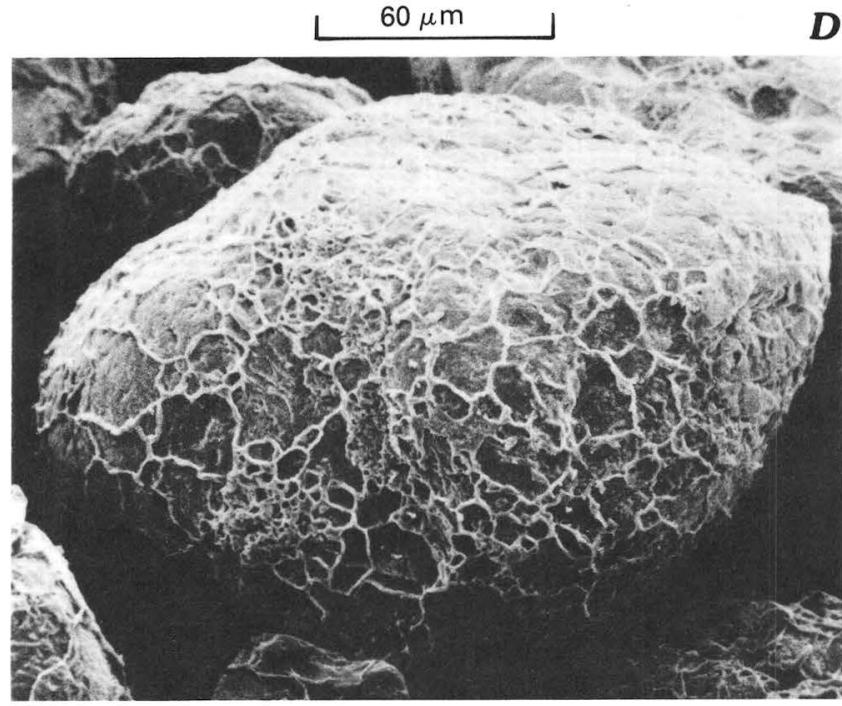

$20 \mu \mathrm{m}$

$E$

$100 \mu \mathrm{m}$

FENSTERMAKER WASH FORMATION, FIGURES $\boldsymbol{A}, \boldsymbol{E}$; AND McCOLLEY CANYON FORMATION, FIGURE $\boldsymbol{F}$ 


\section{PLATE 6}

[Plane-light photomicrographs]

FigURE 1. Davis Spring Formation

1. Specimen $32 \mathrm{~m}$; siliceous-radiolarian-spiculitic-argillaceous dolomite. Section of a radiolarian ( silica) with spines is in center of photograph.

2-6. Kinkead Spring Limestone

2. Specimen $132 \mathrm{~m}$; brachiopod-echinoderm-peloid-ooid packstone to grainstone Echinoderm fragments have syntaxial overgrowths of calcite. The rock is composed of sedimentary particles that reflect diverse origins: peloids, broken fossil remains, and oolitic coated particles. Micrite converted to microspar.

3. Specimen $150 \mathrm{~m}$; peloid-ooid packstone to grainstone. This rock type is typical of the zone 8 and $8 / 9$ ooid beds in Mississippian carbonate rocks. Micrite between ooids has in part been converted to microspar.

4. Specimen $170 \mathrm{~m}$; ostracode-brachiopod wackestone, composed of well-sorted fossil fragments and calcareous spiculites in a 2- to $4-\mu \mathrm{m}$ calcite micrite matrix.

5. Specimen $170.5 \mathrm{~m}$; ostracode-calcisphere-spiculite wackestone.

6. Specimen $178 \mathrm{~m}$; ostracode-calcisphere-spiculite wackestone. Subrounded quartz sand grains 75 to $100 \mu \mathrm{m}$ in size form 1 to 3 percent of rock. Fossil fragments are rounded and well sorted. Lime mudstone (micrite) matrix is 2- to $4-\mu \mathrm{m}$ calcite crystals. This wackestone microfacies is typical of the rock type found associated with ooid packstones and grainstones. 
GEOLOGICAL SURVEY

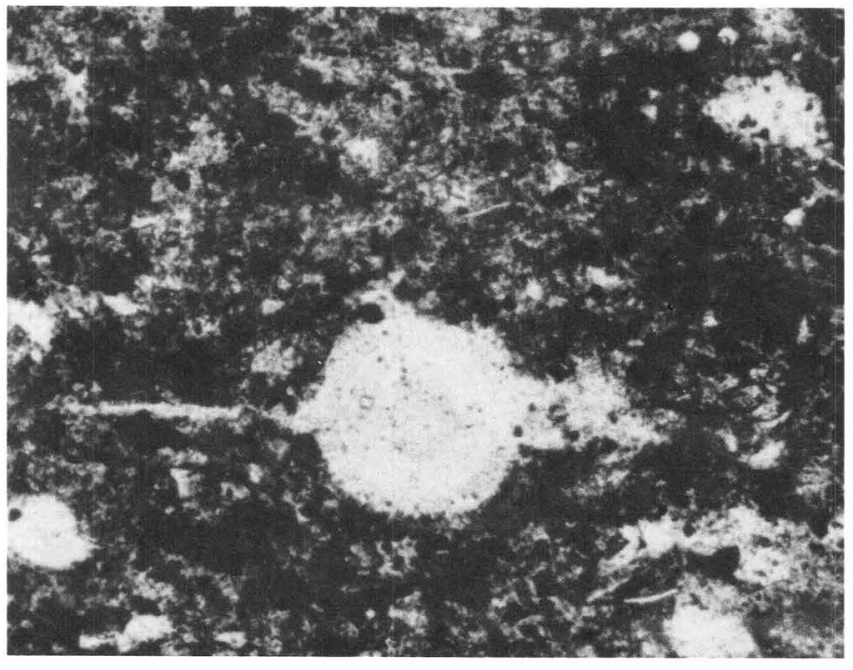

A

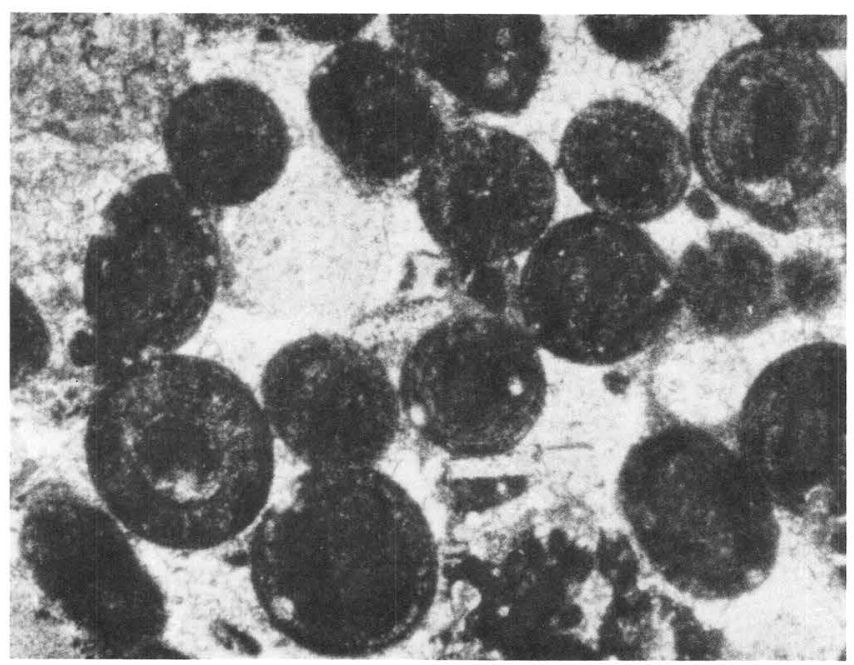

$1 \mathrm{~mm}$

C

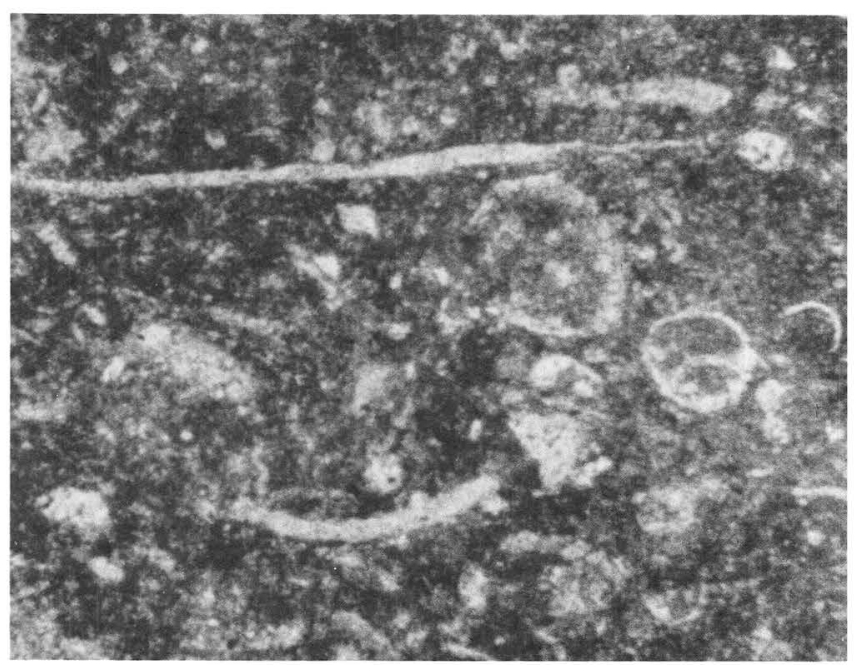

$0.2 \mathrm{~mm}$

$E$
PROFESSIONAL PAPER 1182, PLATE 6

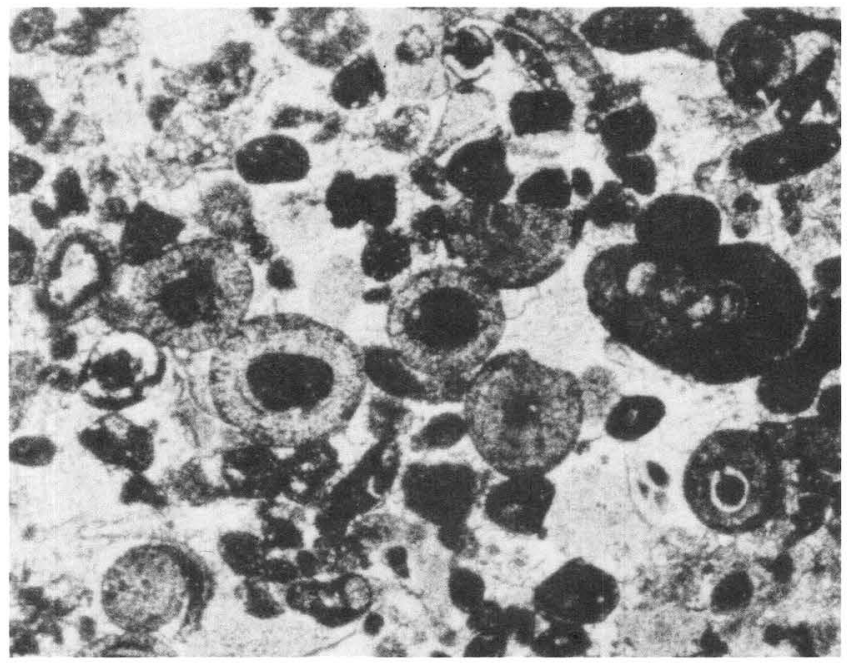

$B$

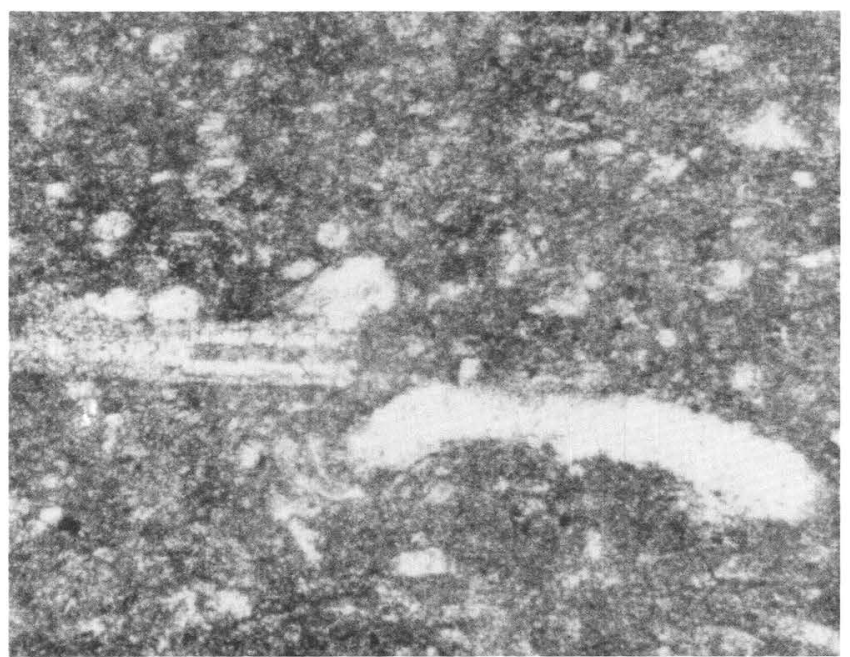

D

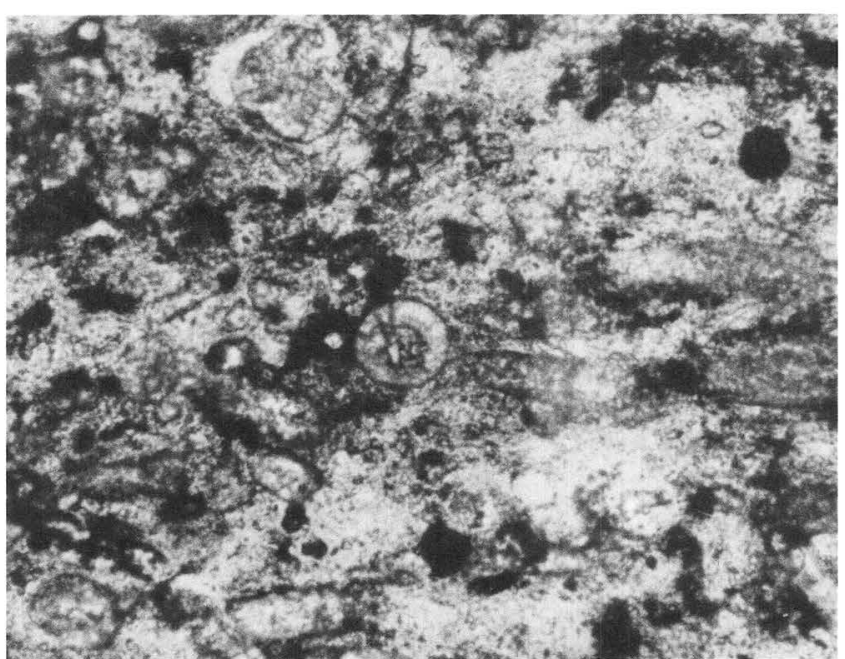

$0.2 \mathrm{~mm}$

F

DAVIS SPRING FORMATION, FIGURE $\boldsymbol{A}$; AND KINKEAD SPRING LIMESTONE, FIGURES $\boldsymbol{B}-\boldsymbol{F}$ 


\section{PLATE 7}

FiguRES 1-17. Scanning electron micrographs of biostratigraphically significant conodonts from the McColley Canyon Formation. Stratigraphic position of USGS collection numbers is shown in text figure 5.

1-3. Icriodus huddlei celtibericus Carls and Gandl. Upper views of I elements showing variation in the angle between the outer lateral process and the main platform. 1. USNM 270001, X 45, USGS colln. 9638-SD.

2, 3. USNM 270002, 270003, X 50, USGS colln. 9637-SD.

4-7. Icriodus huddlei? n. subsp. Upper and lower views of I elements. Representatives of this form occur in the lower $153 \mathrm{~m}$ of the McColley Canyon Formation.

4,5 . USNM 270004, X 50, USGS colln. 9637-SD.

6, 7. USNM 270005, X 40, USGS colln. 9813-SD.

8-9. Icriodus huddlei celtibericus Carls and Gandl. Anterior and posterior views of $\mathrm{S}_{2}$ elements, USNM 270006, 270007, X 45 and X 75. USGS colln. 9654-SD.

10-11. Pandorinellina exigua philipi (Klapper). Upper and lateral views of $\mathrm{P}$ element, USNM 270008, X 50. USGS colln. 9817-SD.

12-13. Pandorinellina steinhornensis miae Bultynck. Upper and oblique lateral views of $P$ element, USNM 270009, X 50. USGS colln. 9818-SD.

14-15. Polygnathus gronbergi Klapper and Johnson. Upper and lower views of $\mathrm{P}$ element, USNM 270010, X 50 USGS colln. 9818-SD.

16-17. Icriodus corniger Wittekindt. Upper and lower views of I elements, USNM 270011, 270012, X 50. USGS colln. 9639-SD.

18-23. Scanning electron micrographs of a "conodont pearl" and biostratigraphically significant conodonts from the Denay Limestone. Stratigraphic position of USGS collection numbers is shown in text figure 5.

18. "Conodont pearl" showing dimple. USNM 270013, X 100. USGS colln. 9819-SD.

19. Polygnathus trigonicus Bischoff and Ziegler. Upper view of $\mathrm{P}$ element, USNM 270014, X 75. USGS colln. 9819-SD.

20,21. Polygnathus parawebbi Chatterton. Upper views of P elements, USNM 270015, 270016, X 50 and X 40. USGS collns. 9814-SD and 9819-SD.

22, 23. Tortodus kockelianus kockelianus Bischoff and Ziegler. Upper and lower views of P element, USNM 270017, X 75. USGS colln. 9814-SD. 


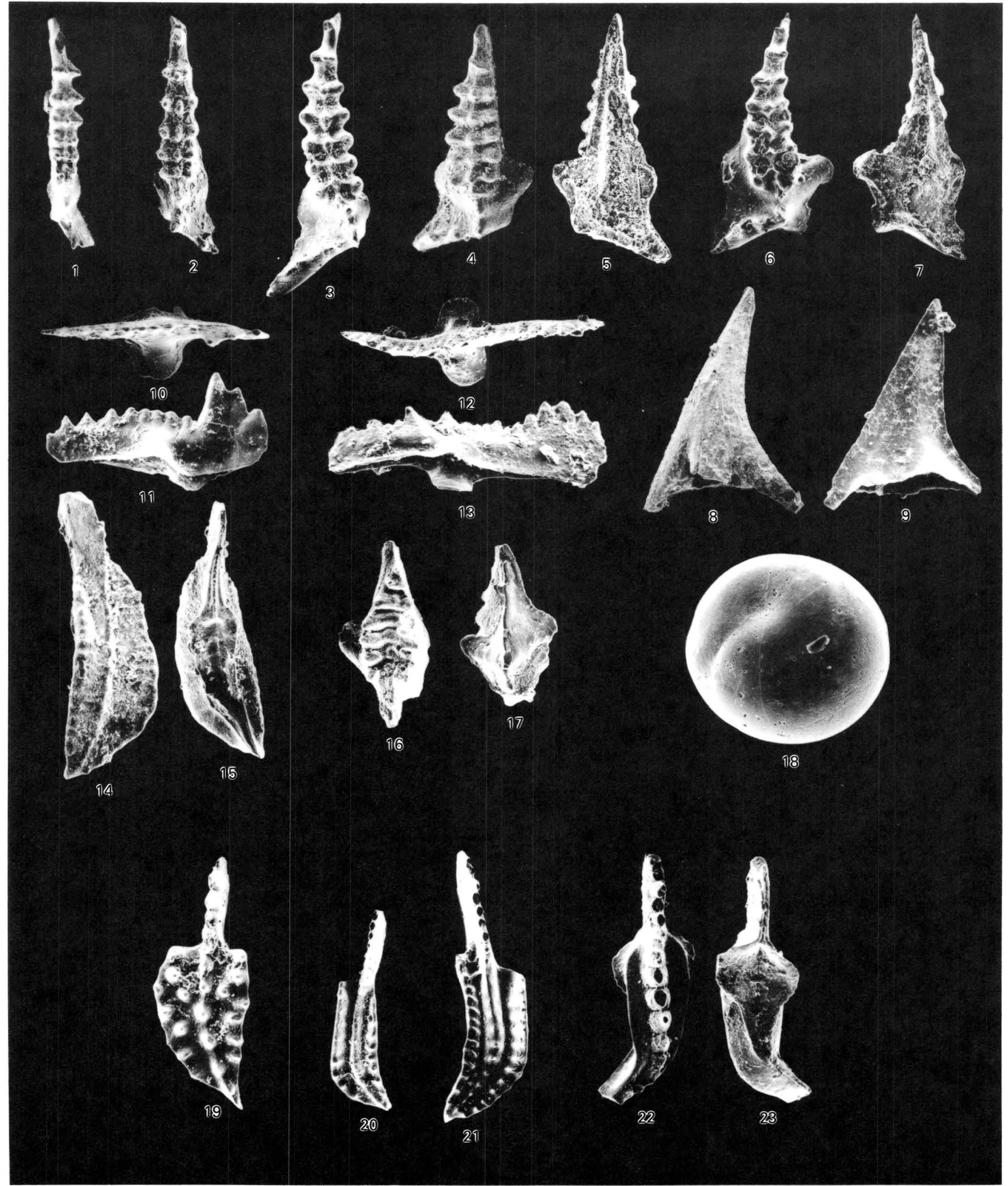

BIOSTRATIGRAPHICALLY SIGNIFICANT CONODONTS FROM THE McCOLLEY CANYON FORMATION AND DENAY LIMESTONE 


\section{PLATE 8}

FIGURES 1-12. Scanning electron micrographs of biostratigraphically significant conodonts from the Fenstermaker Wash Formation. Stratigraphic position of USGS collection numbers is shown in text figure 5 .

1, 2. Polygnathus parawebbi Chatterton. Upper and lower views of $\mathbf{P}$ elements, USNM 270018, 270019, X 50. USGS colln 9815-SD.

3. Polygnathus varcus Stauffer. Upper view of P element, USNM $270020, \mathrm{X} 75$. USGS colln. 9645-SD.

4, 5. Polygnathus decorosus s.1. Upper and lower views of P elements, USNM 270021, 270022, X 50. USGS colln. 9972-SD.

6. Polygnathus norrisi Uyeno. Upper view of P element, USNM 270023, X 63. USGS 9648-SD.

7. Pandorinellina insita (Stauffer). Lateral view of $\mathrm{P}$ element, USNM 270024, X 100. USGS colln. 9648-SD.

8-9. Icriodus symmetricus Branson and Mehl. Upper and lower views of I elements, USNM 270025, 270026, X 50. USGS colln. 9972-SD.

10. Ancyrodella cf. A. buckeyensis Stauffer. Upper view of P element, USNM 270027, X 50. USGS colln. 9972-SD.

11. Palmatolepis cf. P. proversa Ziegler. Upper view of P element, USNM 270028, X 50. USGS colln. 9972-SD.

12. Palmatolepis cf. $P$. hassi Müller and Müller. Upper view of $P$ element, USNM 270029, X 50. USGS colln. 9647-SD.

13-16. Scanning electron micrographs of redeposited Famennian (figs. 13, 14, and 16) and redeposited and (or) indigenous Early Mississippian (fig. 15) condonts from the Davis Spring Formation. All specimens X 50 and from USGS colln. 27377-PC (text fig. 6).

13. Palmatolepis glabra Ulrich and Bassler. Upper view of $\mathrm{P}$ element, USNM 270030. $P$. glabra is the most abundant species among the redeposited elements in this collection.

14. Palmatolepis perlobata Ulrich and Bassler. Upper view of P element, USNM 270031. P. perlobata is one of several species of redeposited Famennian palmatolepids represented by only one or a few specimens in this collection.

15. Gnathodus punctatus (Cooper). Upper view of incomplete P element, USNM 270032.

16. Polygnathus semicostatus Branson and Mehl. Upper view of incomplete P element, USNM 270033. All specimens of this species and at least 90 percent of all the other conodonts in the collection are fragmented and abraded.

17-22. Scanning electron micrographs of redeposited (figs. 17, 18, 20, and 21) and redeposited and (or) indigenous Early Mississippian (figs. 19 and 22) conodonts from the Kinkead Spring Limestone (Osagean). Stratigraphic position of USGS collection numbers is shown in text figure 6 .

17. Coleodus? sp. Lateral view, USNM 270034, X 40. USGS colln. 27411-PC. This specimen is the only recognizable pre-Devonian redeposited element in our collections from the Kinkead Spring Limestone. Coleodus? sp. is common in shelf edge and upper slope facies of the Lower and lower Middle Ordovician Antelope Valley Limestone in central Nevada.

18. Icriodus sp. Upper view of I element, USNM 270035, X 50. USGS colln. 27413-PC. All our collections from the Kinkead Spring Limestone contain I and ( or) $\mathrm{S}_{2}$ elements of redeposited Devonian icriodids.

19. Polygnathus communis Branson and Mehl. Upper view of $\mathbf{P}$ element, USNM 270036, X 50. USGS colln. 27413-PC. The Kinkead Spring Limestone contains Osagean foraminifers and because $P$. communis is known to occur from the Famennian into the middle Osagean, representatives of this species in our collection could be redeposited and (or) indigenous.

20. Siphonodella isosticha (Cooper). Upper view of P element, USNM 270037, X 40. USGS colln. 27411-PC. A redeposited Kinderhookian element.

21. Siphonodella duplicata (Branson and Mehl). Upper view of $\mathrm{P}$ element, USNM 270038, X 40. USGS colln. 27413-PC. Redeposited Kinderhookian element.

22. Gnathodus punctatus (Cooper). Upper view of P element, USNM 270039 , X 50. USGS colln. 27413-PC. A redeposited and (or) indigenous Lower Mississippian element. 


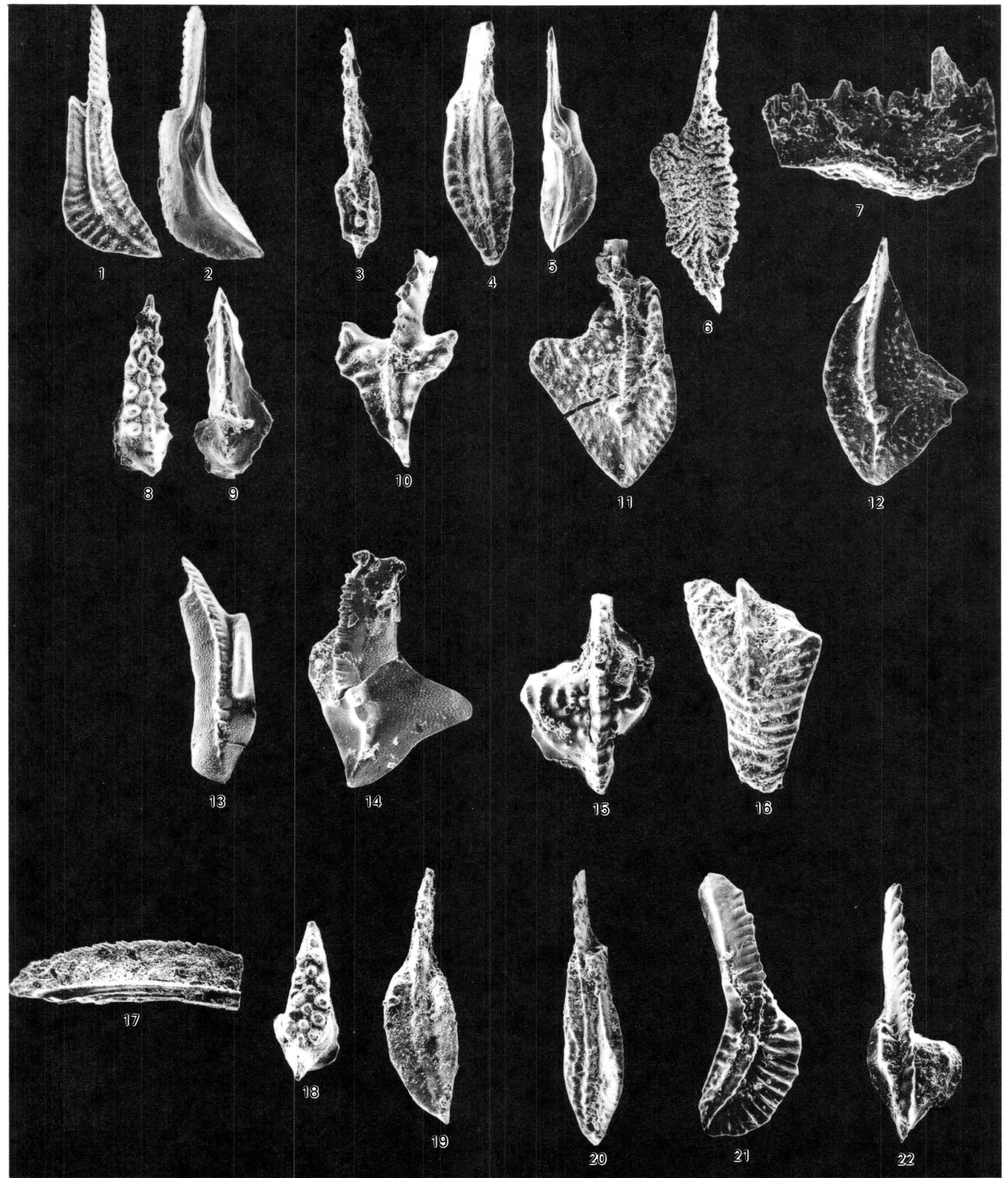

BIOSTRATIGRAPHICALLY SIGNIFICANT CONODONTS FROM THE FENSTERMAKER WASH AND DAVIS SPRING FORMATIONS AND THE KINKEAD SPRING LIMESTONE 
